\title{
Tanin Sebagai Inhibitor Korosi Artefak Besi Cagar Budaya
}

\author{
Ari Swastikawati, Henny Kusumawati, Rifqi Kurniadi Suryanto, Yudi Atmaja Hendra Purnama \\ Balai Konservasi Borobudur \\ Email : arie_swastik@yahoo.com
}

\begin{abstract}
Abstrak : Stabilisasi adalah proses untuk menstabilkan artefak besi yang bertujuan untuk mencegah korosi lanjutan. Proses tersebut dilakukan dengan mengaplikasikan larutan inhibitor. Inhibitor korosi yang sering digunakan dalam proses stabilisasi artefak besi adalah tanin. Tanin merupakan senyawa kimia yang banyak ditemukan pada tanaman. Indonesia memiliki kekayaan alam yang berlimpah salah satunya adalah tanaman yang menghasilkan zat tanin antara lain: teh, daun jambu biji, daun gambir, daun kopi, salak dan sebagainya. Sehingga Indonesia memiliki potensi yang besar untuk mengembangkan tanaman tersebut sebagai inhibitor korosi artefak besi. Kajian Tanin sebagai Inhibitor Korosi Artefak Besi Cagar Budaya bertujuan untuk mengetahui metode aplikasi tanin yang tepat pada artefak besi dan menentukan lingkungan yang sesuai untuk artefak besi yang telah dikonservasi dengan tanin. Metode penelitian yang dilaksanakan dalam kajian ini meliputi studi referensi, observasi dan eksperimen di laboratorium. Eksperimen yang dilakukan meliputi ektraksi teh dari Nglinggo, pengukuran kadar tanin dalam ekstrak teh, dan dilanjutkan dengan uji metode aplikasi tanin dengan berbagai perlakuan. Perlakuan tanin sintetik dibandingkan dengan ekstrak teh. Perlakuan penambahan asam fosfat, dan perlakuan pelapisan dengan paraloid pada sampel besi yang telah diberi tanin. Serta perlakuan pengaruh lingkungan (suhu dan kelembaban) dengan menempatkan sampel besi yang telah diberi tanin di luar ruangan, dalam ruang tanpa AC, dan dalam ruang ber-AC.

Hasil penelitian menunjukan kandungan ekstrak daun teh tua asal Nglinggo 12,11\% dan kandungan ekstrak daun teh mudanya 12,61\%. Kandungan tanin dalam daun teh tua asal Nglinggo 1,78\% dan kandungan tannin dalam daun teh mudanya 2,69\%. Tanin dari ekstrak teh dapat menghambat korosi pada artefak besi namun kemampuannya masih di bawah tanin sintetik. Dalam aplikasi larutan ekstrak untuk stabilisasi besi perlu penambahan asam fosfat untuk mencapai pH optimum. Pelapisan paraloid dibutuhkan jika lapisan tanin besi yang terbentuk tipis. Jika tanin yang terbentuk sudah tebal maka tidak diperlukan lapisan pelindung tambahan. Pelapisan diperlukan pada artefak yang distabilkan dengan ekstrak teh. Lamanya perlindungan kompleks besi-tanin terhadap artefak besi sangat dipengaruhi oleh kondisi lingkungan. Besi yang telah distabilkan dengan tanin dan dilapisi akan lebih terawetkan jika berada pada lingkungan yang stabil dengan kelembaban udara di bawah $50 \%$ jika masih mengandung klor dan di bawah 65\% jika sudah tidak mengandung klor.
\end{abstract}

Kata kunci: tanin, inhibitor, stabilisasi, konservasi, artefak

\begin{abstract}
Stabilization is a process to stabilize iron artifacts that aim to prevent further corrosion. The process is carried out by applying an inhibitor solution. The corrosion inhibitor that is often used in the process of stabilizing the iron artifact is tannin. Tannin is a chemical compound found in plants. Indonesia has a wealth of natural resources that produces tannin substances, such as tea, guava leaves, gambir leaves, coffee leaves, salak and so on. So Indonesia has a great materials to develop such plants as corrosion inhibitor of iron artifacts. "Study of Tannin as a Corrosion Inhibitor on Iron Artifact" aims to know the suitable method of tannin application in the iron artifact and determine the appropriate environment for iron artifacts that have been conserved with tannins. Methods of research conducted in this study include library studies, observations and laboratory experiments. Experiments were conducted on the extraction of tea from Nglinggo, measuring the levels of tannins in the tea extract, and proceed with the test method for application of tannins with various treatments. Treatment of synthetic tannins is compared to the tea extract. Treatment addition of phosphoric acid, and treatment with paraloid coating on iron samples that have been applied tannin. Treatment as well as environmental influences (temperature and humidity) by placing samples of iron, which has been applied tannin, outdoors, in a room without air conditioning, and the air-conditioned room.

The results showed that the content of the old tea leaf extract from Nglinggo is $12.11 \%$ and the content of the young tea leaf extract is $12.61 \%$. The content of tannin in old tea leaves from Nglinggo is $1.78 \%$ and the content of tannin in young tea leaves is $2.69 \%$. Tannins from tea extracts can inhibit corrosion of the iron artefacts but its effectivity is lower than synthetic tannins. In the application of the extract solution for the stabilization of the iron, it is necessary to add phosphoric acid to achieve a pH optimum. Paraloid coating is needed if layer of iron tannin is thinly formed. If tannin is thickly formed, it does not require an additional protective layer. The coating is required on artifacts to stabilise the tea extract. The length of the iron-tannin complex protection on iron artifacts is strongly influenced by environmental conditions. Iron that has been stabilized with tannins and coated will be more preserved if it is in a stable environment with humidity below $50 \%$ if it still contains chlorine and below $65 \%$ if it does not contain chlorine.
\end{abstract}

Keywords: tannin, inhibitors, stabilization, conservation, artifact 


\section{Pendahuluan}

\subsection{Latar Belakang}

Indonesia merupakan negara kepulauan yang memiliki beraneka ragam budaya. Keanekaragaman budaya tersebut menghasilkan beraneka ragam tinggalan cagar budaya pula, yang dapat berupa benda, struktur, bangunan, situs, dan kawasan cagar budaya seperti yang disebutkan dalam Undang-Undang Nomor 11 tahun 2010. Berdasarkan aspek penyusun material cagar budaya dapat dibedakan menjadi cagar budaya berbahan batu, bata, kayu, logam, keramik, kertas dan sebagainya. Supaya cagar budaya tersebut dapat dinikmati oleh generasi mendatang dalam kondisi yang utuh dan lengkap, maka cagar budaya tersebut harus dilestarikan. Dalam upaya pelestarian cagar budaya tersebut maka diperlukan tindakan konservasi.

Berdasarkan bahan serta peralatan yang digunakan maka konservasi cagar budaya dapat dibedakan menjadi konservasi modern dan konservasi tradisional. Konservasi modern adalah tindakan konservasi dengan menggunakan bahan serta peralatan yang relatif modern. Bahan yang direkomendasikan dalam kegiatan konservasi tersebut merupakan hasil penelitian, pengkajian, dan pengembangan dalam bidang konservasi. Adapun yang dimaksud dengan peralatan modern adalah seperangkat peralatan modern yang dibuat atau dapat digunakan untuk kegiatan konservasi. Konservasi tradisional adalah tindakan konservasi menggunakan bahan dan peralatan tradisional yang berpatokan pada kearifan lokal (local wisdom) serta pengalaman yang terakumulasi dalam pengetahuan masyarakat setempat (people knowledge). Peralatan tradisional adalah peralatan sederhana, yang dibuat oleh masyarakat dengan bahan yang diperoleh dari lingkungannya. Bahan tradisional adalah bahan yang didapat dari lingkungan (bahan alam) masyarakat setempat, yang dipercayai dapat digunakan dalam konservasi cagar budaya atas dasar pengalaman dan tradisi turun temurun (Sunarno, 2010). Saat ini terdapat kecenderungan di dunia untuk kembali menggunakan bahan alam dalam penanganan konservasi cagar budaya. Kecenderungan ini didasarkan pada fakta bahwa penggunaan metode tradisional lebih mudah dan ramah terhadap lingkungan.

Indonesia memiliki potensi yang cukup besar untuk mengembangkan bahan alam sebagai bahan konservasi cagar budaya. Hal ini karena Indonesia memiliki kekayaan alam yang berlimpah. Beberapa bahan alam telah diteliti dan dikembangkan oleh Balai Konservasi Borobudur sebagai bahan konservasi antara lain cengkeh, pelepah pisang, gambir, dan tembakau untuk konservasi kayu, jeruk nipis untuk membersihkan kuningan, perunggu dan besi, penggunaan batu apung untuk polishing gamelan, penggunaan santan untuk pembersihan perunggu, dan sebagainya.

Terkait dengan konservasi besi, dalam tahapan akhir kegiatan konservasi terdapat proses stabilisasi. Stabilisasi adalah proses untuk menstabilkan artefak besi yang bertujuan untuk mencegah korosi lanjutan. Proses stabilisasi dilakukan setelah proses pembersihan dan pengeringan selesai. Proses tersebut biasanya dilakukan dengan cara merendam artefak besi dalam larutan inhibitor. Inhibitor korosi yang sering digunakan dalam proses stabilisasi artefak besi adalah tanin. Tanin merupakan senyawa kimia yang banyak ditemukan pada tanaman, antara lain: teh, daun jambu biji, daun gambir, daun kopi, dan salak. Tanaman-tanaman tersebut umumnya tersebar luas di seluruh wilayah Indonesia. Sehingga Indonesia memiliki potensi yang besar untuk mengembangkan tanaman tersebut sebagai inhibitor korosi artefak besi. Oleh karena itu dalam tahun 2015 ini Balai Konservasi Borobudur telah melakukan kajian tentang "Tanin sebagai Inhibitor Korosi Artefak Besi”. Hasil penelitian menunjukan bahwa (1) waktu perendaman 5 hari dalam ekstrak teh dan tanin sintetik tidak menunjukkan adanya perbedaan perlakuan yang signifikan sedangkan waktu perendaman 10 dan 15 hari menunjukan adanya perbedaan perlakuan yang signifikan, (2) waktu perendaman 10 hari menunjukan larutan ekstrak teh 5000 ppm memiliki laju korosi plat besi paling rendah yakni $0,000475590 \mathrm{gr} / \mathrm{cm}^{2} /$ hari dengan efisiensi penghambatan sebesar 45,33\%, (3) waktu perendaman 15 hari menunjukan larutan tanin sintetik 5000 ppm memiliki laju korosi plat besi paling rendah yakni 0,000402987 gr/ $\mathrm{cm}^{2} /$ hari dengan efisiensi penghambatan korosi sebesar $35,78 \%$.

Keseluruhan hasil penelitian tersebut menunjukan bahwa ekstrak teh dan tanin sintetik memiliki kemampuan dalam menghambat korosi besi. Namun, dalam kajian ini belum dapat menentukan metode aplikasi yang tepat serta pengaturan lingkungan yang sesuai setelah artefak dikonservasi dengan tanin. Oleh karena itu, pada tahun 
2016 Balai Konservasi Borobudur telah melanjutkan kajian "Tanin sebagai Inhibitor Korosi Artefak Besi Cagar Budaya Tahap II", untuk menentukan metode aplikasi yang tepat, serta menentukan lingkungan yang paling sesuai setelah artefak dikonservasi dengan tanin.

\subsection{Maksud dan Tujuan}

Maksud dari kajian ini adalah mengetahui metode aplikasi tanin yang tepat pada artefak besi dan menentukan lingkungan yang sesuai untuk artefak besi yang telah dikonservasi dengan tanin. Adapun tujuan dari kajian ini adalah:

1. Membandingkan metode aplikasi tanin (tanin dari ekstrak teh dan tanin sintetik) yang berbeda terhadap kondisi artefak besi.

2. Membandingkan kondisi lingkungan yang berbeda terhadap kondisi artefak besi yang dikonservasi dengan tanin (tanin dari ekstrak teh dan tanin sintetik).

\subsection{Manfaat}

Manfaat yang diharapkan dalam kajian ini adalah tersedianya metode aplikasi tanin yang tepat dalam konservasi artefak besi dan persyaratan kondisi lingkungan yang sesuai setelah artefak besi dikonservasi dengan tanin.

\subsection{Ruang Lingkup}

Kajian tentang tanin sebagai inhibitor korosi artefak besi dibatasi pada penggunaan tanin yang berasal dari ekstrak teh dan membandingkannya dengan tanin sintetik.

\section{Landasan Teori}

\subsection{Artefak Logam dalam Arkeologi}

Indonesia memiliki cagar budaya berupa artefak logam dengan jumlah berlimpah yang tersebar di seluruh wilayah nusantara. Artefak-artefak tersebut memiliki bentuk dan fungsi yang beraneka ragam serta beraneka ragam pula bahan penyusunnya. Artefak-artefak logam tersebut merupakan sumber data primer dalam arkeologi. Menurut Mircea dkk (2010), material arkeologi secara lengkap dapat menggambarkan kronologi evolusi manusia dari tinjauan perkembangan ekonomi dan kehidupan sosial masyarakat serta hubungannya dengan kebudayaan dengan peradaban sebelumnya. Oleh karena itu artefakartefak logam sebagai material arkeologi tersebut harus dilestarikan. Ditambahkan pula oleh Mircea dkk (2010), jika material arkeologi tersebut dipertimbangkan dalam kaitannya dengan degradasi yang dialami pada beberapa kondisi, pada kondisi keterawatanya dan mekanisme perubahan logam di dalam tanah berturut-turut dari aspek fisik (fragmen, retakan, lubang dan sebagainya), aspek kimia pembentukan kerak korosi pada bagian terbesar tanpa atau dengan bagian tengah dari logam dapat digunakan untuk menguraikan beberapa kesimpulan terkait dengan hal tersebut. Dari aspek arkeometalorgi, teknologi masa lalu, metode yang digunakan untuk menghasilkan objek atau asal dari logam-logam yang digunakan di dalamnya.

\subsection{Artefak Logam Berbahan Besi}

Artefak logam berbahan logam besi banyak ditemukan di Indonesia mulai dari yang berukuran kecil hingga besar seperti keris, tombak, meriam, lokomotif, pesawat, kapal perang dan sebagainya. Besi merupakan jenis logam kedua yang paling melimpah di bumi dan masih menjadi tulang punggung dalam peradaban modern. Ketergantungan terhadap logam tersebut dinyatakan oleh penggunaannya dalam kehidupan manusia, mulai dari keperluan rumah, pertanian, permesinan, hingga alat transportasi (Herman, 2006). Besi memiliki sifat fisika antara lain pada suhu kamar berwujud padat, mengkilap dan berwarna keabu-abuan dan merupakan penghantar panas yang baik. Adapun sifat kimia besi antara lain unsur besi bersifat elektro positif (mudah melepaskan elektron) sehingga bilangan oksidasinya bertanda positif, logam murni besi sangat reaktif secara kimiawi dan mudah terkorosi, khususnya di udara yang lembab atau ketika terdapat peningkatan suhu, mudah bereaksi dengan unsur-unsur non logam seperti halogen, sulfur, fosfor, boron, karbon dan silikon, larut dalam asam-asam mineral encer dan sebagainya. Ada tiga jenis besi yaitu:

a. Besi tempa adalah logam yang komposisinya terdiri dari besi murni dan besi silikat.

b. Besi tuang adalah besi dengan kadar karbon di atas $1.7 \%$ meskipun biasanya besi tuang memiliki kadar karbon 3 - $4.5 \%$. Besi tuang banyak digunakan dalam dunia teknik dan industri karena karakteristik atau sifat mach inability yang mudah 
dikerjakan dengan mesin dan memiliki sifat tahan aus karena bersifat self lubrication. Besi tuang dibagi menjadi 2 bagian yaitu :

- Besi tuang kelabu: sebagian besar dari zat arang atau karbon dalam besi tuang ini terpisah sebagai graphite. Bidang patahan dari besi tuang ini berwarna abu-abu tua sampai hitam.

- Besituangputih:dimanasebagianbesarkarbon yang terikat dalam besi sebagai zementite $\left(\mathrm{Fe}_{3} \mathrm{C}\right)$ yang keras. Besi tuang ini memiliki bidang patahan yang berwarna putih. Sifat yang keras sehingga sukar dikerjakan di mesin.

c. Baja merupakan perpaduan antara besi $(\mathrm{Fe})$ dan karbon (C). Besi adalah elemen metal dan karbon adalah elemen non metal. Baja sendiri digolongkan menjadi dua golongan yaitu baja bukan paduan (yang hanya terpadu dengan karbon saja) dan baja paduan yaitu yang terpadu dengan elemen - elemen lain sesuai dengan kebutuhan dan sifat yang dikehendaki. Elemen paduan yang ditambahkan itu sendiri terdiri dari mangan, chrome, nickel, wolfram, silisium, dan lainnya (Munandar, 2007).

\subsection{Korosi pada Besi}

Definisi korosi menurut Trethewey dan Chemberlain (1991:4) adalah penguraian dan kehilangan bahan oleh agresi kimia dan korosi merupakan gejala destruktif yang mempengaruhi hampir semua logam sedangkan karat (rust) merupakan sebutan yang hanya dikhususkan bagi korosi pada besi. Maa $\beta$ and Peibker (2011) mengatakan bahwa korosi adalah interaksi logam dengan lingkunganya yang menghasilkan perubahan sifat logam dan mungkin menyebabkan gangguan fungsional yang signifikan pada logam.

Faktor yang berpengaruh dan mempercepat korosi yaitu air dan kelembaban udara, elektrolit berupa asam atau garam, adanya oksigen, permukaan logam yang tidak rata serta letak logam dalam potensial reduksi. Air merupakan salah satu faktor penting untuk berlangsungnya proses korosi. Udara yang banyak mengandung uap air (lembab) akan mempercepat berlangsungnya proses korosi. Elektrolit berupa asam ataupun garam merupakan media yang baik untuk melangsungkan transfer muatan.
Hal itu mengakibatkan elektron lebih mudah untuk dapat diikat oleh oksigen di udara. Oleh karena itu, air hujan (asam) dan air laut (garam) merupakan penyebab utama terjadinya korosi. Pada peristiwa korosi adanya oksigen mutlak diperlukan. Permukaan logam yang tidak rata memudahkan terjadinya kutub-kutub muatan, yang akhirnya akan berperan sebagai anode dan katode. Pada permukaan logam yang licin dan bersih korosi tidak mudah terjadi, sebab sukar terbentuk kutub-kutub yang akan bertindak sebagai anode dan katode. Korosi akan sangat cepat terjadi pada logam yang potensialnya rendah, sedangkan logam yang potensialnya lebih tinggi justru lebih tahan. Besi merupakan logam yang mudah teroksidasi, lebih-lebih bila berada di tempat dengan kondisi udara yang lembab. Reaksi kimia korosi besi adalah sebagai berikut :

$$
4 \mathrm{Fe}(\mathrm{s})+3 \mathrm{O}_{2}(\mathrm{aq}) \stackrel{\mathrm{H}_{2} \mathrm{O}}{\longrightarrow} 2 \mathrm{Fe}_{2} \mathrm{O}_{3}(\mathrm{~s}) \text { (karat besi }
$$
berwarna kuning)

Pada tingkat awal bentuk oksidasi besi adalah ferro oxida $(\mathrm{FeO})$, lama kelamaan akan berubah menjadi ferri oksida $\left(\mathrm{Fe}_{2} \mathrm{O}_{3}\right)$. Pembentukan karat akan dipercepat oleh udara yang sudah tercemar sulfur dioksida dan klor $(\mathrm{Cl})$. Di samping itu reaksi tersebut akan dipicu oleh adanya bakteri-bakteri tertentu. Berdasarkan hasil penelitian bakteri pereduksi sulfat dari jenis Desulforibrio disulfucaus mempunyai peran yang cukup berarti dalam korosi (Sadirin, 1991: 84).

Jenis korosi pada logam dibedakan menjadi korosi pasif dan korosi aktif. Korosi pasif terjadi sebagai lapisan oksida yang stabil atau perubahan warna yang terjadi secara perlahan-lahan pada permukaan artefak logam. Lapisan oksida tersebut akan melindungi permukaan logam yang mendasarinya. Sehingga lapisan oksida tersebut sering dianggap sebagai patina. Adapun ciri-ciri korosi pasif pada artefak besi adalah sebagai berikut (Logan, 2007): (1) bersifat stabil, kompak, dan melekat, (2) memiliki variasi dalam warna antara biruhitam dan merah-coklat

Korosi aktif adalah jenis korosi yang menyebabkan kehilangan material yang berkelanjutan pada objek. Adapun ciri-ciri umum korosi aktif pada logam adalah (1) luas permukaan yang mengalami korosi bertambah dengan cepat, (2) adanya pengelupasan 
sehingga di sekitar artefak ditemukan serpihan, fragmen atau bubukan (loose powder) sebagai produk korosi, (3) adanya lekukan atau semacam lepuhan pada permukaan, (4) adanya bintik-bintik berwarna orange pada pusatpusat lekukan, (5) adanya retakan pada permukaan artefak besi, (6) adanya "sweating" or "weeping (berkeringat dan menangis) berupa tetesan pada permukaan objek yang berwarna kuning, coklat atau orange yang terjadi pada lingkungan dengan RH sangat tinggi di atas 55\%, area artefak besi yang mengalami "sweating" or "weeping" disebabkan oleh kontaminasi ion klorida, (7) jika kelembaban menurun di bawah 50\% maka area yang mengalami "sweating" or "weeping" akan mengering dan melepuh yang berwarna orange atau kuning. Oleh karena itu penting untuk mengidentifikasi jenis-jenis korosi pada artefak besi sebelum melakukan tindakan konservasi (Swastikawati, A. 2014).

\subsection{Pengertian Konservasi}

Konservasi berasal dari kata conservation yang terdiri atas kata con (together) dan servare (keep/save) yang memiliki pengertian mengenai upaya memelihara apa yang kita punya (keep/save what you have), secara bijaksana (wise use). Ide ini dikemukakan oleh Theodore Roosevelt (1902). Rosevelt merupakan orang Amerika pertama yang mengemukakan tentang konsep konservasi. Terkadang ada yang memaknai konservasi sama dengan preservasi, tetapi adapula yang sebaliknya preservasi lebih luas dari konservasi atau sebaliknya. Di Inggris dan Australia definisi konservasi lebih cenderung kepada konservasi lingkungan, dimana konservasi merupakan pelestarian secara luas sedangkan preservasi merupakan perawatan secara kimiawi. Tetapi berbeda dengan negara-negara di Eropa seperti Prancis, Itali, dan Belgia dimana konservasi merupakan bagian dari pemeliharaan yang menangani perawatan secara kimiawi sedangkan preservasi merupakan pelestarian dalam arti umum yang mencakup perlindungan hukum, dokumentasi, pemeliharaan dan pemugaran.

Di Indonesia definisi konservasi menurut Balai Pustaka (1980) meliputi pemeliharaan perlindungan sesuatu secara teratur untuk mencegah kerusakan dan kemusnahan dengan jalan mengawetkan. Kata konservasi dalam UU No.11 tahun 2010 tetang Cagar Budaya tidak disebutkan namun dalam undang-undang tersebut disebutkan tentang pelestarian dan pemeliharaan. Definisi pelestarian adalah upaya dinamis untuk mempertahankan cagar budaya dan nilainya dengan cara melindungi, mengembangkan dan memanfaatkan sedangkan definisi pemeliharaan adalah upaya menjaga dan merawat agar kondisi fisik cagar budaya tetap lestari.

Tindakan konservasi dapat dilakukan melalui langkah preventif dengan konservasi preventif(pencegahan) dan langkah kuratif dengan konservasi kuratif (penanggulangan atau perawatan). Berdasarkan sasaran yang diperlakukan maka konservasi benda cagar budaya dapat dibedakan menjadi dua yaitu konservasi aktif dan konservasi pasif. Konservasi aktif adalah segala tindakan konservasi yang dikenakan langsung ke bendanya. Adapun konservasi pasif adalah tindakan konservasi yang tidak secara langsung dikenakan ke bendanya tetapi tindakan konservasi dilakukan dalam bentuk pengendalian lingkungan (Swastikawati, A., 2011:1).

Sementara itu berdasarkan bahan serta peralatan yang digunakan maka konservasi cagar budaya dapat dibedakan menjadi konservasi tradisional dan konservasi modern. Konservasi tradisional adalah tindakan konservasi dengan menggunakan bahan dan peralatan tradisional yang berpatokan pada kearifan lokal (local wisdom) serta pengalaman yang terakumulasi dalam pengetahuan masyarakat setempat (people knowledge). Bahan tradisional adalah bahan yang didapat dari lingkungan masyarakat setempat, yang dipercayai dapat digunakan dalam konservasi cagar budaya, atas dasar pengalaman dan tradisi turun temurun. Peralatan tradisional adalah peralatan sederhana, yang dibuat oleh masyarakat dengan bahan yang diperoleh dari lingkungannya. Konservasi modern adalah tindakan konservasi dengan menggunakan bahan serta peralatan yang relatif modern. Bahan yang direkomendasikan dalam kegiatan konservasi tersebut merupakan hasil penelitian, pengkajian dan pengembangan dalam bidang konservasi, sedangkan yang dimaksud dengan peralatan modern adalah merupakan seperangkat peralatan modern yang dibuat atau dapat digunakan untuk kegiatan konservasi (Sunarno, 2010).

\subsection{Metode Konservasi Logam}

Tahapan dalam metode konservasi logam meliputi (1)pembersihan kerak secara mekanis, (2) evaluasi kondisi logam dan (3)pelaksanaan konservasi. 
Adapun pelaksanaan kegiatan konservasinya meliputi (1) pembersihan, (2)perbaikan, (3)konsolidasi, (4)stabilisasi atau pelapisan dan (5)penyimpanan. Pembersihan yang dimaksud meliputi pembersihan secara kimiawi, pembersihan secara elektrokimia, dan pembersihan secara elekto reduksi (Munandar, 2014). Berdasarkan ulasan tersebut, maka kegiatan konservasi logam yang dapat dilakukan dengan memanfaatkan bahan alam atau bahan tradisional adalah pada tahap pembersihan karat secara kimia melalui proses perendaman, pengosokan maupun pengolesan dan tahap stabilisasi dan pelapisan artefak logam. Stabilisasi artefak logam dapat dilakukan dengan aplikasi inhibitor korosi logam

\subsection{Inhibitor Korosi Logam dari Ektrak Tanaman}

Pencegahan korosi besi dapat dilakukan dengan cara pelapisan pada permukaan logam, perlindungan katodik, penambahan inhibitor korosi, dan lain-lain. Penggunaan inhibitor merupakan salah satu cara yang paling efektif untuk mencegah korosi karena biayanya yang relatif murah dan prosesnya yang sederhana (Hermawan, B. 2007). Suatu inhibitor adalah zat kimia yang dapat menghambat atau memperlambat suatu reaksi kimia. Inhibitor korosi didefinisikan sebagai suatu zat yang apabila ditambahkan dalam jumlah sedikit ke dalam lingkungan akan menurunkan serangan korosi terhadap logam. Mekanisme kerja inhibitor dalam menghambat korosi pada logam sebagai berikut (Dalimunthe, IS. 2004):

1. Inhibitor terabsorpsi pada permukaan logam dan membentuk suatu lapisan tipis (film), sehingga tidak dapat dilihat oleh mata.

2. Inhibitor mengendap, selanjutnya teradsorpsi pada permukaan logam sehingga melindungi logam dari korosi. Lapisan yang terbentuk dapat diamati oleh mata.

3. Inhibitor lebih dahulu mengkorosi logamnya dan menghasilkan zat kimia, melalui proses absorpsi produk kimia tersebut membentuk lapisan pasif pada permukaan logam

4. Inhibitor menghilangkan konstituen yang agresif dari lingkungan

Inhibitor korosi umumnya berasal dari senyawasenyawa organik dan anorganik yang mengandung gugus-gugus yang memiliki pasangan elektron bebas, seperti nitrit, kromat, fosfat, urea, fenilalanin, imidazolin, dan senyawa-senyawa amina. Namun pada kenyataannya bahan kimia sintesis merupakan bahan kimia yang berbahaya, harganya mahal, dan tidak ramah lingkungan. Oleh karena itu solusi penggunaan inhibitor dari ekstrak tanaman sangat diperlukan. Hal ini karena inhibitor yang berasal dari ekstrak tanaman umumnya lebih aman, mudah didapatkan, bersifat biodegradable, biaya murah, dan ramah lingkungan (Hermawan, B. 2007).

Ekstrak tanaman khususnya senyawa yang mengandung atom N, O, P, S, dan atom-atom yang memiliki pasangan elektron bebas. Unsur-unsur yang mengandung pasangan elektron bebas dapat berfungsi sebagai ligan yang akan membentuk senyawa kompleks dengan logam. Efektivitas ekstrak tanaman sebagai inhibitor korosi tidak terlepas dari kandungan nitrogen yang terdapat dalam senyawa kimianya (Hermawan,B. 2007). Salah satu inhibitor korosi yang terdapat dalam ekstrak tanaman adalah tannin.

\subsection{Tanin sebagai Inhibitor Korosi Artefak Besi}

Sejarah penggunaan tanin sebagai inhibitor korosi besi diawali oleh penemuan arkeologi berupa artefak besi dalam kondisi sangat utuh dan terawetkan, yang ditemukan terkubur dalam media yang mengandung tanin alam. Dalam situs ini ditemukan benda-benda besi masih tetap terawat dengan baik pada lokasi penyamakan kulit Saxon di York, dimana media tanah sebenarnya sangat mendukung untuk proses korosi. Sekalipun sebenarnya jauh sebelum penemuan artefak-artefak tersebut sudah dilakukan penelitian tentang tanin dalam menghambat korosi besi. Dengan ditemukanya artefakartefak tersebut semakin menguatkan penelitian peran tanin dalam melindungi besi dari korosi (Pelikan, 1966).

Tanin merupakan senyawa organik yang terdistribusi luas pada tanaman. Hampir setiap famili tanaman mengandung tanin seperti yang terdapat dalam buah-buahan dan sayur-sayuran. Apabila tanin terbentuk dalam jumlah yang cukup pada tanaman maka akan ditempatkan pada bagian daun, buah, kulit kayu dan batang. Teh memiliki kandungan tannin yang cukup besar yaitu 20-30\% dari berat kering daun teh. Tanin adalah kelompok polifenol yang larut dalam air dengan berat molekul antara 500-3000 gr/mol. Berdasarkan struktur kimianya dapat digolongkan menjadi dua kelas yakni (Fajriati, I. 2006): 


\section{Condensed tannin}

Merupakan tanin yang dapat terkondesasi dan tidak dapat dihidrolisis kecuali dalam suasana asam, contoh katekin, proantocyanidin.

\section{Hidrolisable tannin}

Tanin yang terhidrolisis dalam air, contoh galotanin, cafetanin.

Tanin lebih dikenal sebagai asam tanat yang biasanya mengandung $10 \%$ air $\left(\mathrm{H}_{2} \mathrm{O}\right)$. Struktur kimia tanin merupakan struktur kimia yang kompleks dan tidak sama.

Senyawa polifenol dalam tanin mampu menghambat proses oksidasi. Polifenol merupakan senyawa turunan fenol yang mempunyai aktivitas sebagai antioksidan. Fungsi polifenol dapat sebagai penangkap dan pengikat radikal bebas dari rusaknya ion-ion logam. Tanin memiliki sifat antara lain dapat larut dalam air atau alkohol karena tanin banyak mengandung fenol yang memiliki gugus $\mathrm{OH}$, yang dapat mengikat logam berat (Carter et al, 1978 dalam Irianty dan Komalasari, 2013). Menurut Logan (2013), bila tanin diaplikasikan pada besi, maka asam tanat bereaksi dengan ion besi membentuk (ferric tannate) tanin besi, yang berwana biru-hitam.

\section{Metode Penelitian}

\subsection{Metode Penelitian}

Adapun metode penelitian yang dilaksanakan dalam kajian ini meliputi studi referensi, observasi dan experimen di laboratorium dengan penjelasan sebagai berikut:

1. Studi Referensi

Studi referensi atau studi pustaka dimaksudkan untuk mendapatkan data atau referensi, baik dalam bentuk buku, artikel, jurnal dan sebagainya yang memiliki relevasi dengan kajian ini. Penelusuran referensi dilakukan di perpustakaan Balai Konservasi Borobudur, perpustakaan Jurusan Arkeologi, Fakultas Ilmu Budaya, perpustakaan Fakultas MIPA UGM serta penelusuran referensi melalui internet.

2. Observasi

Observasi dilaksanakan melalui kegiatan pengamatan pada koleksi di Museum Nasional Jakarta. Kegiatan tersebut bertujuan mengevaluasi lingkungan (suhu dan kelembaban) dimana koleksi artefak besi yang telah dikonservasi dengan tanin ditempatkan di Museum Nasional.

3. Eksperimen dan analisis laboratorium Eksperimen dilaksanakan untuk menentukan metode aplikasi yang tepat serta menentukan lingkungan yang sesuai untuk artefak besi yang telah dikonservasi dengan tannin. Analisis laboratorium dilakukan untuk mendukung hasil kajian.

\subsection{Rancangan Eksperimen}

Perkembangan metode konservasi pada artefak besi dilakukan untuk mencegah korosi dalam jangka waktu yang lama. Menurut Pelikan (1966), treatment tannin pada lapisan berkarat sebagai cara pencegahan korosi aktif pada lapisan di bawahnya. Treatment ini disarankan sebagai persiapan permukaan logam sebelum dicoating dengan vernis berwarna atau transparan. Namun demikian, dalam artikel Logan (2013), menyatakan tidak diajurkan mengaplikasikan vanish, minyak ataupun wax setelah artefak besi diaplikasi dengan tanin. Oleh karena itu, dalam kajian ini dilakukan pengujian metode aplikasi tanin.

Adapun rancangan eksperimen dalam kajian "Tanin sebagai Inhibitor Korosi Artefak Besi Cagar Budaya Tahap II", sebagai berikut:

a. Perlakukan dengan metode aplikasi tanin yang berbeda pada plat besi

1. Kontrol / tanpa aplikasi tanin $10 \%$

2. Aplikasi tanin dari esktrak teh $10 \%$, dalam aplikasinya menggunakan 2 metode:

- dengan penambahan etanol dan tanpa penambahan asam fosfat

- tanpa coating

- dicoating paraloid B 72 5\%

- dengan penambahan etanol dan asam fosfat

- tanpa coating

- dicoating paraloid B 72 5\%

3. Aplikasi tanin sintetik $10 \%$, dalam aplikasinya menggunakan 2 metode:

- Dengan penambahan etanol dan tanpa penambahan asam fosfat

- tanpa coating 
- dicoating paraloid B72 5\%

- Dengan penambahan etanol dan asam fosfat

- tanpa coating

- dicoating paraliod B72 5\%

b. Perlakuan dengan lingkungan yang berbeda setelah plat besi diaplikasi dengan tanin.

1. Ditempatkan dalam ruangan tanpa AC

2. Ditempatkan dalam ruangan ber-AC

\section{Ditempatkan di luar ruangan}

Tempatkan data logger pada tiap lokasi

Adapun tabel rancangan percobaan seperti tertera dalam Tabel 1. di bawah ini:

\subsection{Alat dan Bahan}

a. Alat

1. Data logger 3 buah

\section{Tabel 1. Rancangan Percobaan}

$\begin{array}{cccc}\begin{array}{c}\text { Variasi Waktu } \\ \text { (hari) }\end{array} & \begin{array}{c}\text { RTD } \\ \text { Diletakan di } \\ \text { ruang tanpa AC }\end{array} & \begin{array}{c}\text { RTD } \\ \text { Diletakan di } \\ \text { ruang ber- AC }\end{array} & \begin{array}{c}\text { RTD } \\ \text { Diletakan diluar } \\ \text { ruangan }\end{array} \\ \text { Ekstrak Teh (T) } & \text { K.1 } & \text { K.2 } & \text { K.3 } \\ \text { T NF NP } & \text { T.1.1 } & \text { T.1.2 } & \text { T.1.3 } \\ \text { T NF P } & \text { T.2.1 } & \text { T.2.2 } & \text { T.2.3 } \\ \text { TF NP } & \text { T.3.1 } & \text { T.3.2 } & \text { T.3.3 } \\ \text { TF P } & \text { T.4.1 } & \text { T.4.2 } & \text { S.1.3 } \\ \text { Tanin Sintetik } & & & \text { S.2.3 } \\ \text { (S) } & & \text { S.1.2 } & \text { S.3.3 } \\ \text { S NF NP } & \text { S.1.1 } & \text { S.2.2 } & \text { S.4.3 }\end{array}$

Keterangan Kode

\section{Kontrol (K)}

Ekstrak Teh (T)

\begin{tabular}{cl} 
T NF & Tanpa Asam Fosfat (NF) \\
\hline T NF NP & tanpa dicoating Paraloid (NP) \\
T NF P & dicoating dengan Paraloid (P) \\
T F & Dengan Asam Fosfat (F) \\
T F NP & tanpa dicoating Paraloid (NP) \\
T F P & dicoating dengan Paraloid (P)
\end{tabular}

Tanin Sintetik (S)

$$
S N F
$$

S NF NP

S NF P

$S F$

$S F N P$

S F P
Tanpa Asam Fosfat (NF)

tanpa dicoating Paraloid (NP)

dicoating dengan Paraloid $(P)$

Dengan Asam Fosfat (F)

tanpa dicoating Paraloid (NP)

dicoating dengan Paraloid $(P)$ 
2. digital mikroskop

3. komputer

4. nampan plastik

5. beker glass

6. kuas alat pengamplas spatula

7. termometer

8. spatula glass

9. stirrer

10. pemanas

b. Bahan

1. sampel plat besi

2. bubuk tanin sintetik Merck

3. daun teh kering

4. aquabidest (air demineralisasi)

5. tissue

6. ampelas

7. asam fosfat $\left(\mathrm{H}_{3} \mathrm{PO}_{4}\right)$

8. aseton

9. toluen

10. $\mathrm{pH}$ indikator

11. sampel besi

12. silika gel

13. reagen Folin Ciocalteu

14. larutan $\mathrm{Na}_{2} \mathrm{CO}_{3}$

15. asam oksalat

16. Indikator asam

17. Digosulfonat

\subsection{Prosedur Eksperimen}

a. Prosedur Ektraksi Tanin Cara I

Untuk membuat ekstrak teh maka disiapkan daun teh yang muda (pucuk) dan yang tua. Daun teh yang telah dipetik dipisahkan antara yang tua dan muda kemudian dikeringkan dengan cara di-angin-anginkan di bawah sinar matahari. Selajutnya dilakukan ekstraksi dengan 2 metode di bawah ini:

\section{Metode 1: Perendaman dalam air}

Daun teh kering sebanyak 50 gr direndam dalam air panas $\left(70^{\circ} \mathrm{C}\right), 500 \mathrm{ml}$ selama 8 jam. Kemudian disaring menggunakan air bersih, selanjutnya dievaporasi dalam oven sampai kering dengan suhu $60^{\circ} \mathrm{C}$.

2. Metode 2: Perendaman dalam air dan
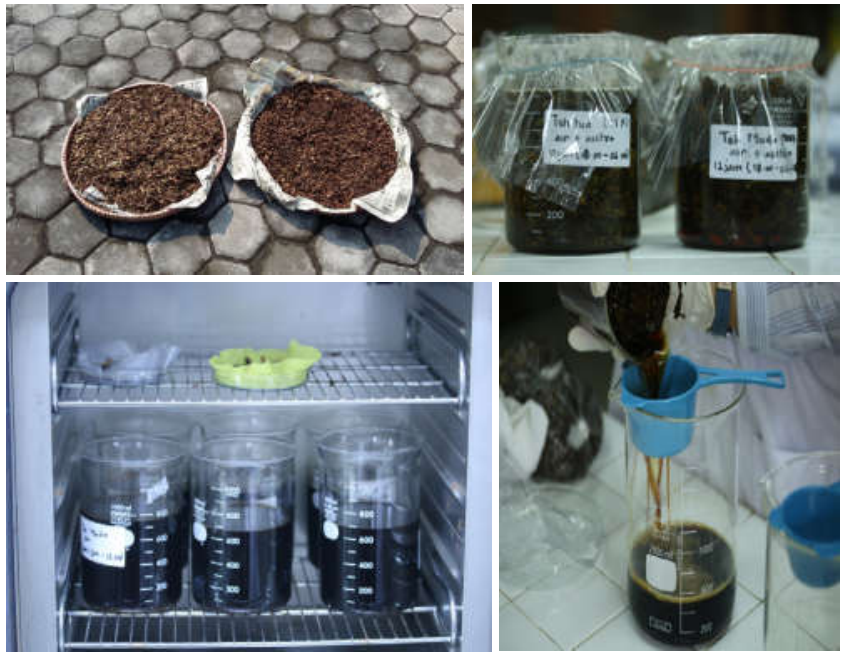

Prosedur Ekstraksi Tanin I

aseton $(80 \%)$

Daun teh kering 50 gr direndam dalam larutan air + aseton(1:3) 500 selama 12 jam, kemudian disaring menggunakan kain bersih selanjutnya dievaporasi dalam oven pada suhu $40^{\circ} \mathrm{C}$ sampai diperoleh kristal tanin.

Selanjutnya penentuan kadar ekstrak tanin. Kadar ekstrak tanin ditentukan berdasarkan bubuk serbuk kering oven daun teh yakni dengan menentukan kadar air serbuk kering udara. Serbuk kering oven ditentukan dengan persamaan sebagai berikut:

Bobot serbuk kering oven $=\frac{\text { Bobot Serbuk Kering Udara }}{1+K A \text { Serbuk kering udara }}$

Ekstrak kering oven yang diperoleh sebagai ditimbang sebagai bobot ekstrak, kemudian kadar ekstrak dihitung dengan menggunakan persamaan

Kadar Ekstrak $(\%)=\frac{\text { Bobot Serbuk Kering Oven }}{\text { Bobot Ekstrak }} \times 100 \%$

(Kusmayadi, 1989 dalam Siregar, 2009).

b. Prosedur Ektraksi Tanin II

1. Bahan dan Alat

Bahan yang digunakan adalah daun teh muda dan tua yang sudah kering, dekstrin, tween 80 . Alat-alat yang digunakan adalah timbangan analitis, gelas ukur, blender, ayakan 100 mesh, mixer, loyang, pengering kabinet, labu ukur, 
erlenmeyer, cawan petri, kertas saring, dan eksikator.

\section{Prosedur Ektraksi}

- Menimbang $50 \mathrm{~g}$ daun teh kering yang telah dicuci bersih.

- Menambah air sebanyak $500 \mathrm{ml}$ lalu memblender sampai halus, kemudian direbus sampai mendidih selama 15 menit.

- Menyaring sari daun teh dan mengambil airnya sebagai ekstrak (filtrate) dan mendinginkannya.

- Menambahkan dekstrin 5\% dan Tween 80 sebanyak $5 \mathrm{ml}$ pada ekstrak daun the lalu dimixer selama10 menit sehingga menjadi busa.

- Busa dituang pada loyang yang telah diberi alas plastik dan dikeringkan dalam dalam oven selama 24 jam pada suhu $60^{\circ} \mathrm{C}$.

- Setelah ekstrak kering dihaluskan menggunkan blender hingga berbentuk bubuk.

- Mengayak bubuk ekstrak daun teh dengan ayakan 100 mesh hingga diperoleh produk dengan ukuran seragam.

c. Penetapan Kadar Tanin Secara

Spektrofotometri

1. Penentuan Panjang Gelombang Maksimum Ditimbang tanin sintetik sebanyak 10,0 mg, dilarutkan dan ditambahkan aqua demineralisata sampai volume $100,0 \mathrm{ml}$ sehingga didapatkan baku induk 100,0 bpj.
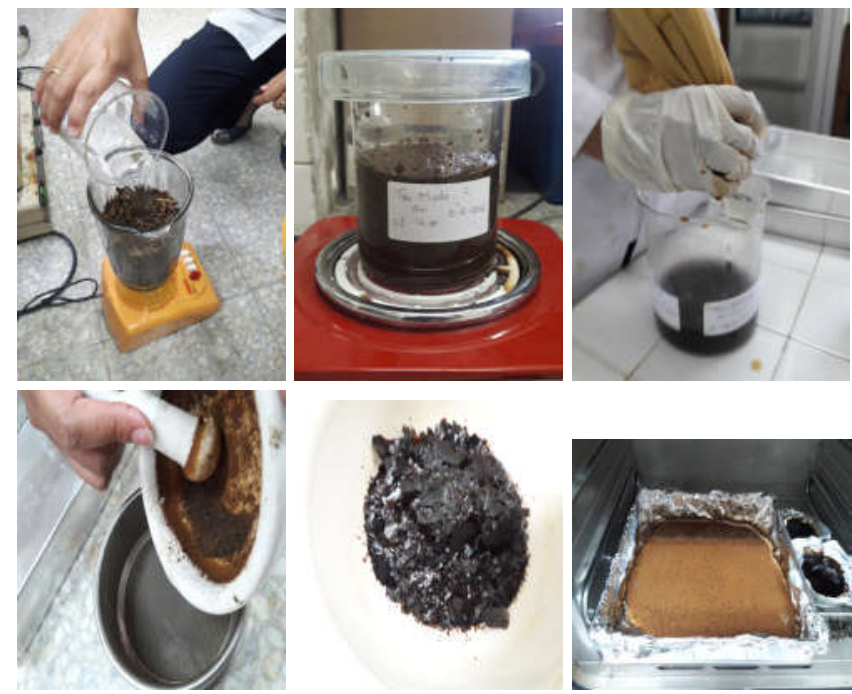

Prosedur Ekstraksi II
Larutan baku induk tanin sintetik dipipet sejumlah tertentu dan dimasukkan ke dalam labu ukur 10,0 ml, ditambahkan $1 \mathrm{ml}$ reagen Folin Ciocalteu, kemudian dikocok dan didiamkan selama 5 menit. Larutan tersebut ditambah $2 \mathrm{ml}$ larutan $\mathrm{Na}_{2} \mathrm{CO}_{3}$ 15\%, dikocok homogen dan didiamkan selama 5 menit. Selanjutnya ditambahkan aqua demineralisata sampai tepat $10,0 \mathrm{ml}$ dan dibaca pada panjang gelombang pada rentang $\lambda$ 500-900 nm.

2. Penentuan Waktu Stabil

Larutan baku induk tanin sintetik dipipet sejumlah tertentu dan dimasukkan ke dalam labu ukur 10,0 ml, ditambahkan 1 $\mathrm{ml}$ reagen Folin Ciocalteu, kemudian dikocok dan didiamkan selama 5 menit. Larutan tersebut ditambah $2 \mathrm{ml}$ larutan $\mathrm{Na}_{2} \mathrm{CO}_{3} 15 \%$, dikocok homogen dan didiamkan selama 5 menit. Selanjutnya ditambahkan aqua demineralisata sampai tepat 10,0 $\mathrm{ml}$. Lalu diamati absorbansinya pada $\lambda 765 \mathrm{~nm}$ dengan interval waktu pengamatan $0,5,10,15,20$, 25, 30,35, 40, 45, 50, 55, 60, sampai 110 menit pada panjang gelombang maksimum.

3. Pembuatan Kurva Baku tanin sintetik

Larutan baku induk tanin sintetik di ambil dengan pipet sejumlah tertentu dan dimasukkan ke dalam labu ukur 10,0 ml lalu ditambahkan $1 \mathrm{ml}$ reagen Folin Ciocalteu. Dikocok dan diamkan selama 5 menit. Kemudian ditambah $2 \mathrm{ml}$ larutan $\mathrm{Na}_{2} \mathrm{CO}_{3}$ 15\%, dikocok homogen (hingga merata) dan didiamkan selama 5 menit. Selanjutnya ditambahkan air demineralisasi sampai tepat volume $10,0 \mathrm{ml}$. Dikocok homogen dan didiamkan selama 90 menit. Lalu diamati absorbansi pada panjang gelombang maksimum. Dilakukan pengambilan larutan baku induk tanin sintetik sejumlah tertentu sebanyak enam kali hingga didapatkan tujuh konsentrasi dan dibuat kurva baku standar tanin sintetik.

4. Penetapan Kadar Tanin Total

Sebanyak 50,0 mg ekstrak teh dilarutkan dengan air demineralisasi sampai volume 


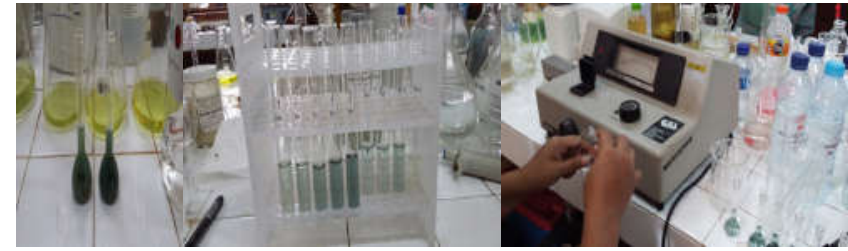

Pengukuran Kadar Tanin dengan Spektrofotometri

50,0 ml. Larutan ekstrak yang diperoleh kemudian di ambil dengan pipet sejumlah tertentu dan ditambah $1 \mathrm{ml}$ reagen Folin Ciocalteu, kemudian dikocok dan didiamkan selama 5 menit. Larutan tersebut ditambah 2 ml larutan $\mathrm{Na}_{2} \mathrm{CO}_{3} 15 \%$, dikocok homogen dan didiamkan selama 5 menit. Selanjutnya ditambahkan air demineralisasi sampai volume 10,0 ml. Diamkan pada interval waktu stabil yang diperoleh. Absorbansi larutan ekstrak diamati pada panjang gelombang maksimum. Konsentrasi yang didapatkan dilakukan replikasi sebanyak dua kali. Kadar tanin total dihitung ekuivalen dengan tanin sintetik (Tannic Acid dari Merck).

a. Pembuatan larutan tanin ekstrak teh sebanyak $25 \mathrm{ml}$

Larutan Inhibitor tanin ekstrak teh $10 \%$, dengan etanol dan tanpa asam fosfat

Timbang 2,50 gram ekstrak teh tambahkan aquades panas $23 \mathrm{ml}$, tambahkan ethanol 1,75 diaduk kemudian dimasukan ke dalam labu ukur, dan tambahkan aquadest hingga volume $25 \mathrm{ml}$.

Larutan Inhibitor ekstrak teh 10\%, dengan etanol dan asam fosfat.

Timbang 2,5 gram ekstrak teh, tambahkan aquades panas $23 \mathrm{ml}$, biarkan beberapa saat lalu tambahkan etanol $1,75 \mathrm{ml}$ dan asam fosfat encer $0,05 \mathrm{ml}$, diaduk kemudian masukan ke dalam labu ukur dan tambahkan aquadest hingga volume $25 \mathrm{ml}$.

b. Pembuatan larutan inhibitor tannin sintetik sebanyak $50 \mathrm{ml}$

Larutan Inhibitor tanin sintetik $10 \%$, dengan etanol dan tanpa asam fosfat

Timbang 5 gram tanin sintetik, tambahkan air panas $45 \mathrm{ml}$ lalu biarkan biarkan sesaat, Kemudian tambahkan $3 \mathrm{ml}$ etanol diaduk lalu masukan ke dalam labu ukur tambahkan aquadest hingga volume $50 \mathrm{ml}$.

Larutan Inhibitor tanin sintetik 10\%, dengan etanol dan asam fosfat

Timbang 5 gram tanin sintetik, tambahkan air panas $45 \mathrm{ml}$ biarkan biarkan sesaat. Kemudian tambahkan etanol $3 \mathrm{ml}$ dan asam fosfat encer $0,1 \mathrm{ml}$ diaduk, lalu masukan ke dalam labu ukur tambahkan aguadest hingga volume $50 \mathrm{ml}$.

c. Pembuatan larutan paraloid 5\% sebanyak $100 \mathrm{ml}$

Timbang paraloid 5 gram, masukan ke dalam beker glass. Kemudian masukan $90 \mathrm{ml}$ toluen campur hingga homogen mengunakan stirrer. Masukan larutan paraloid tersebut ke dalam labu ukur $100 \mathrm{ml}$, tambahkan toluene sampai volume $100 \mathrm{ml}$, kemudian dikocok hingga homogen.

d. Langkah-langkah dalam eksperimen

Pembersihan sampel plat besi dengan cara direndam dalam air sodium karbonat $\left(\mathrm{Na}_{2} \mathrm{HCO}_{3}\right) 3 \%$ untuk menghilangkan residu chloride dan membunuh beberapa jenis bakteri secara umum selama 3 bulan.

Setelah itu sampel dibersihkan karatnya dengan air jeruk nipis sampai bersih dengan cara disikat

Setelah karat bersih, sampel besi diicuci dengan aquabides dikeringkan dan dimasukan dalam exikator. Setelah benar benar kering dimasukan dalam plastik dan diberi silika gel, sebelum dilajutkan tindakan berikutnya.

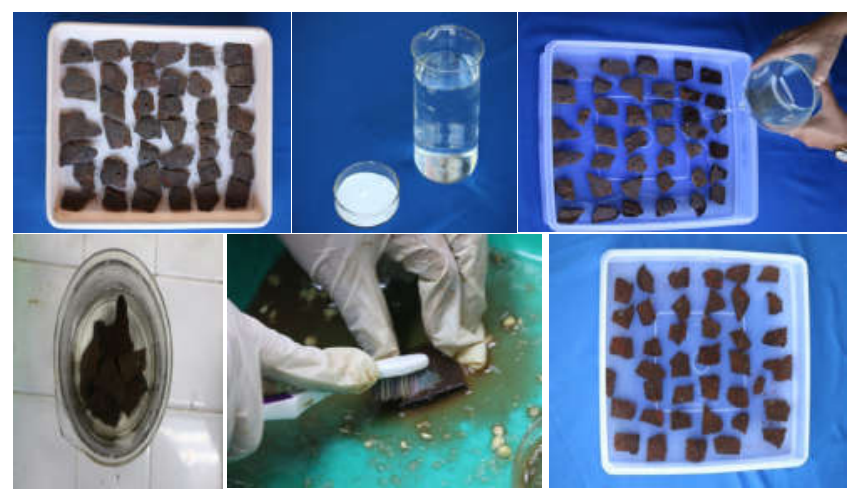

Perlakuan Terhadap Sampel Sebelum Eksperimen 


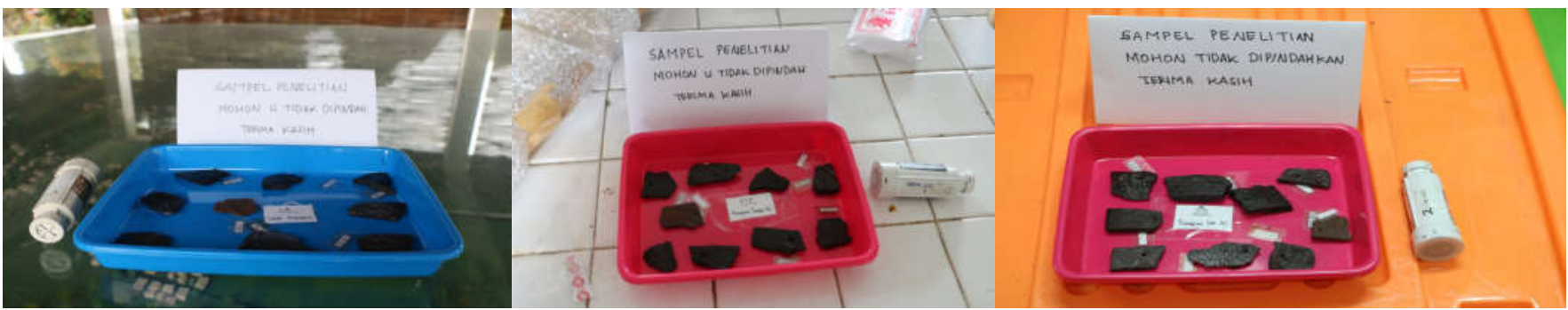

Sampel diletakan di luar ruangan (kiri), dalam ruangan tanpa AC (tengan) dan dalam ruangan ber-AC (kanan)

1. Sampel besi untuk kontrol yaitu besi setelah dibersihkan tidak diberi perlakuan apapun. Satu buah sampel besi diletakan dalam ruangan tanpa AC, Satu buah sampel besi diletakan dalam ruangan ber-AC, satu buah sampel besi diletakan di luar ruangan.

2. Sisanya 32 sampel plat besi yang diberi perlakuan seperti yang tertera pada table dan ditempatkan pada tiga lokasi dengan kondisi lingkungan yang berbeda seperti pada kontrol.

3. Dilakukan pengamatan perubahan permukaan plat besi setelah 1, 3, 6, 12, 18, 24 hari dan seterusnya menggunakan digital mikroskop. Perubahan permukaan diamati pada sampel besi yang terkorosi dan tidak terkorosi.

\section{Hasil Pembahsan}

\subsection{Kandungan Tanin Dalam Daun Teh yang Berasal dari Nglinggo}

Ektraksi daun teh dengan cara perendaman, penambahan dextrin dan tween 80 serta dilanjutkan pengovenan dapat dipeloleh ekstrak daun teh tua 12,11\% dan ekstrak daun teh muda 12,61\%, seperti tertera dalam Tabel 4.1 di bawah ini:

Ekstrak dari daun teh tua dan muda tersebut selanjutnya dianalisis dengan alat spetrofotometri untuk mengetahui kandungan tanin dalam ekstrak tersebut. Berdasarkan hasil pengukuran nilai absorbansi larutan

Tabel 4.1 Kadar Ekstrak Teh dari Nglinggo Kulonprogo standard tanin sintetik dari Merck diperoleh persamaan $\mathrm{Y}=0,074 \mathrm{X}+$ 0,030 (lihat Grafik 4.1). Nilai absorbansi daun teh tua 0,12 sedangkan nilai absorbansi daun teh muda adalah 0,19 .

Berdasarkan persamaan $\mathrm{Y}=0,074 \mathrm{X}+0,030$ tersebut maka dapat diketahui kandungan tanin pada ekstrak daun teh tua 14,78\% dan kandungan tanin dalam ekstrak teh muda 21,35\%. Sehingga diketahui kandungan tanin dalam daun teh tua $1,78 \%$ dan kandungan tanin dalam daun teh muda 2,69\% (llihat Tabel 4.2). Hasil tersebut menunjukan daun teh muda memiliki kandungan tanin lebih tinggi dari daun teh tua.

\subsection{Pengaruh Metode Aplikasi Tanin}

1. Pengaruh Tanin dari Ekstrak Teh dan Tanin Sintetik

Dalam kajian ini dilakukan pengujian pengaruh perlakuan aplikasi tanin dari ekstrak teh dan tanin sintetik pada sampel besi dibandingkan dengan sampel kontrol (tanpa perlakuan).

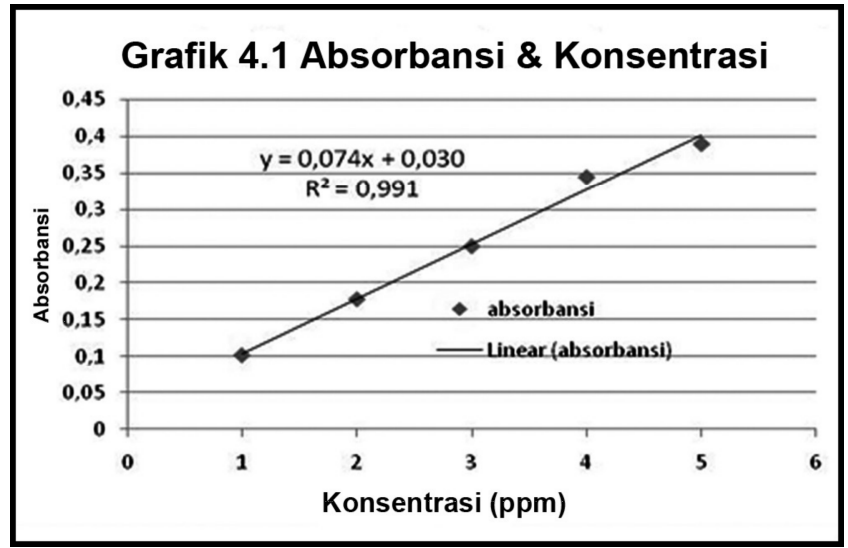

\begin{tabular}{cccccccc} 
No & Daun Teh & $\begin{array}{c}\text { Berat Kering } \\
\text { Udara }(\mathrm{gr})\end{array}$ & $\begin{array}{c}\text { Berat Kering } \\
\text { Oven }(\mathrm{gr})\end{array}$ & $\begin{array}{c}\text { Kandungan } \\
\text { air (\%) }\end{array}$ & $\begin{array}{c}\text { Bobot Ekstrak } \\
(\mathrm{gr})\end{array}$ & $\begin{array}{c}\text { Kadar Ekstrak } \\
(\%)\end{array}$ \\
\hline 1 & Tua & 50 & 45,37 & 10,2 & 5,50 & 12,11 \\
2 & Muda & 50 & 45,66 & 9.5 & 5,76 & 12,61 \\
\hline
\end{tabular}


Tabel 4.2 Kadar Tanin Dalam Daun Teh Nglinggo dengan Analisis Spektrofotometri

\begin{tabular}{|c|c|c|c|c|c|c|}
\hline No & Jenis Larutan & $\begin{array}{l}\text { konsentrasi } \\
\text { (ppm) }\end{array}$ & absorbansi & $\begin{array}{c}\text { Kadar Ekstrak } \\
(\%)\end{array}$ & $\begin{array}{l}\text { Kadar tanin dlm } \\
\text { ekstrak \% }\end{array}$ & $\begin{array}{l}\text { Kadar tanin dlm } \\
\text { daun teh }(\%)\end{array}$ \\
\hline \multirow[t]{6}{*}{1} & standar & & & & & \\
\hline & & 1 & 0,102 & & & \\
\hline & & 2 & 0,178 & & & \\
\hline & & 3 & 0,25 & & & \\
\hline & & 4 & 0,345 & & & \\
\hline & & 5 & 0,39 & & & \\
\hline 2 & teh tua & 1,21 & 0,12 & 12,11 & 14,73 & 1,78 \\
\hline 3 & teh muda & 2,15 & 0,19 & 12,61 & 21,35 & 2,69 \\
\hline
\end{tabular}

Hasil pengamatan setelah 8 minggu perlakuan menunjukan bahwa kondisi permukaan sampel kontrol (K.1.1, K.2.1, K.3.1) berbeda dengan sampel yang diaplikasi dengan tanin dari ekstrak teh maupun tanin sintetik. Permukaan sampel kontrol seluruhnya telah mengalami korosi aktif sedangkan pada sampel yang diaplikasi dengan tanin belum menampakan adanya korosi aktif. Namun, sampel besi yang diaplikasi dengan tanin dari ekstrak teh (T.1.1, T.2.1, T.3.1) dibandingkan dengan tanin sintetik (S.1.1, S.2.1 dan S.3.1) menunjukan degradasi warna yang berbeda. Perbedaan degradasi warna kemungkinan disebabkan oleh ketebalan lapisan kompleks besi-tanin (ferri-tannat) yang berbeda. Lapisan kompleks besi-tanin pada perlakuan tanin sintetik lebih tebal dibandingkan pada tanin dari ektstrak teh. Kondisi ini menunjukan pembentukan kompleks besi-tanin pada permukaan sampel besi dengan perlakuan tanin sintetik lebih banyak dibandingkan pada sampel besi dengan perlakuan tanin dari ekstrak teh. Hal ini karena kandungan tanin sintetik lebih besar (99\%) dibandingkan tannin dari ekstrak teh yang lebih rendah $(14,73-21,35 \%)$. Hasil percobaan ini menunjukan bahwa ekstrak teh dapat menghambat korosi pada artefak besi namun kemampuannya masih di bawah tanin sintetik.

2. Pengaruh Penambahan Asam Fosfat

Dalam kegiatan ini dilakukan pengujian pengaruh penambahan asam fosfat dalam aplikasi tanin. Sebelum eksperimen dilaksanakan, dilakukan pengukuran $\mathrm{pH}$ larutan. Hasil pengukuran $\mathrm{pH}$ larutan tertera dalam Tabel 4.3

Selanjutnya dilakukan pengujian pengaruh pemberian asam fosfat dalam aplikasi tanin terhadap sampel besi. Perlakuan meliputi sampel yang diaplikasi larutan tanin tanpa penambahan asam fosfat (T.1.1, T.1.2, T.1.3, T.2.1, T.2.2, T.2.3, S.1.1, S.1.2, S.1.3, S.2.1, S.2.2, dan S.2.3) dan larutan tanin dengan penambahan asam fosfat (T.3.1,T.4.1, T.3.2, T.4.2, T,3.3, T.4.3, S.3.1, S.4.1, S.3.2, S.4.2, S,3.3, dan S.4.3) baik pada tanin dari ekstrak teh maupun tanin sintetik. Permukaan sampel yang diaplikasi dengan larutan tanin yang ditambah asam fosfat menunjukan reaksi perubahan warna yang lebih cepat dibandingkan dengan permukaan sampel yang diaplikasi dengan larutan tanin tanpa penambahan asam fosfat. Namun, hasil pengamatan terhadap permukaan sampel yang diaplikasi larutan tanin

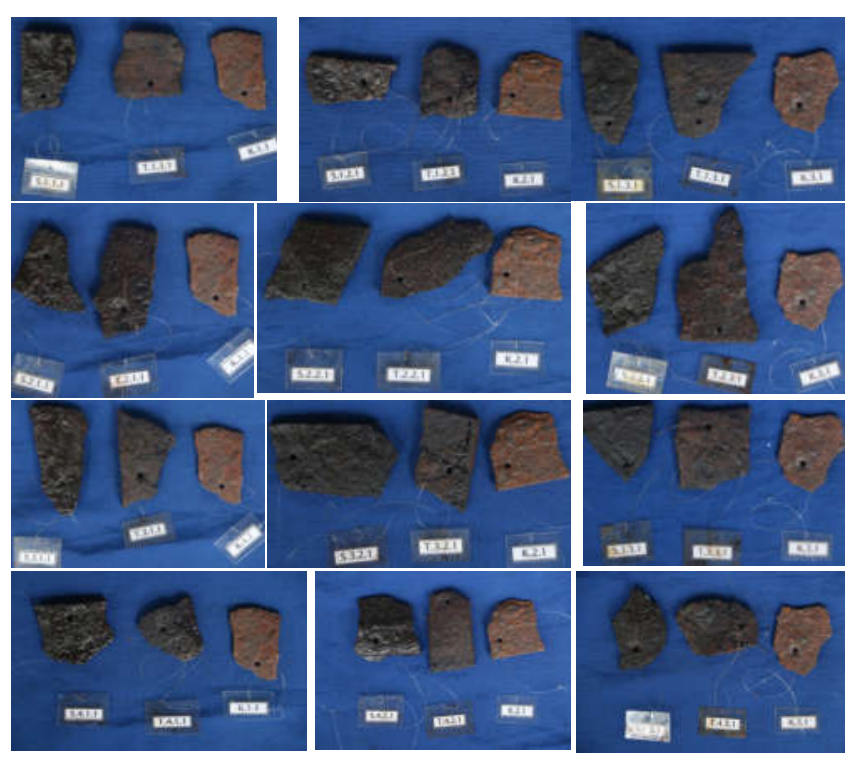

Kontrol, Perlakuan Tanin dari Ekstrak Teh dan Tanin Sintetik 
Tabel 4.3 Jenis Larutan dan pH Larutan

\begin{tabular}{|lc|}
\hline \multicolumn{1}{|c}{ Jenis Larutan } & pH larutan \\
\hline EKSTRAK TEH + ETANOL & 5 \\
\hline EKSTRAK TEH + ETANOL + ASAM FOSFAT & 4 \\
\hline TANIN SINTETIK + ETANOL & $2-3$ \\
\hline TANIN SINTETIK + ETANOL + ASAM FOSFAT & $1-2$ \\
\hline
\end{tabular}

tanpa penambahan asam fosfat dan dengan penambahan asam fosfat menunjukan tidak ada perbedaan secara signifikan setelah 8 minggu perlakuan. Kemungkinan penambahan asam fosfat hanya menyebabkan $\mathrm{pH}$ larutan tanin menjadi lebih rendah yang menyebabkan ion besi menjadi lebih cepat tersedia. Sehingga reaksi pembentukan kompleks besi tanin menjadi lebih cepat. Hal ini sesuai dengan pernyataan Logan, Juddy (2013), asam fosfat menurunkan $\mathrm{pH}$ larutan, dan meningkatkan jumlah ion besi terlarut untuk bereaksi dengan asam tanat. Hal ini dibuktikan pada Table 4.3 yang menunjukan penambahan asam fosfat menyebabkan penurunan $\mathrm{pH}$ larutan menjadi lebih asam.

Menurut Hamilton, D (1999) pH optimun larutan tanin adalah 2,5 sampai 3. Oleh karena itu, $\mathrm{pH}$ 2-3 pada larutan tanin sintetik ditambah etanol sudah mendekati $\mathrm{pH}$ optimum larutan tanin untuk stabilisasi besi. Sehingga aplikasi

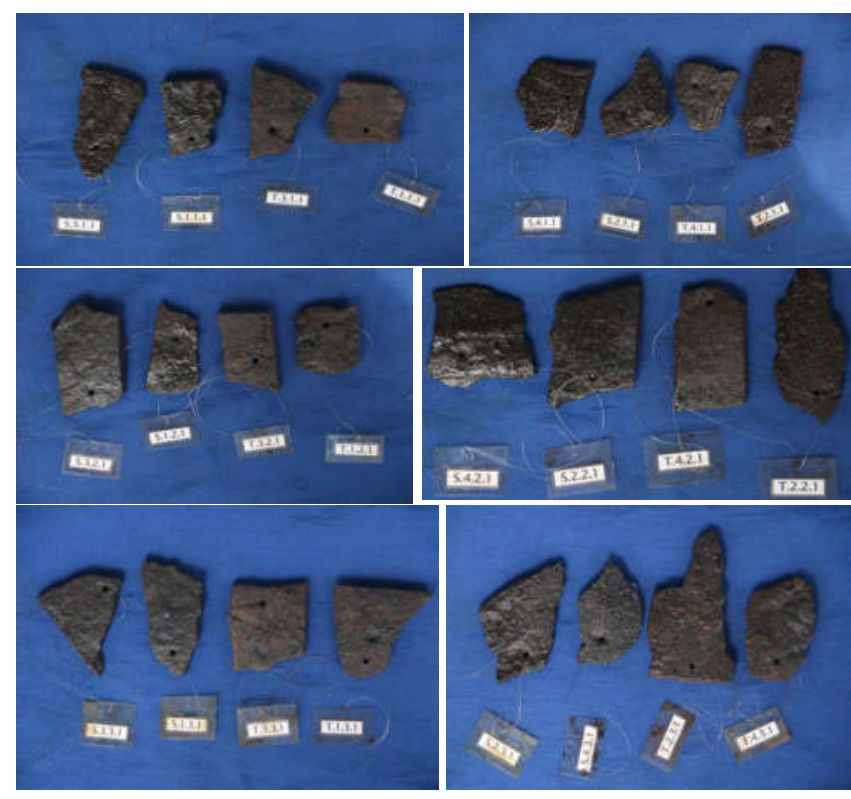

Perlakuan larutan tanin tanpa penambahan asam fosfat dan larutan tanin dengan penambahan asam fosfat tanin sintetik tidak perlu ditambahkan larutan asam fosfat encer. Namun, dalam aplikasi tanin dari ekstrak teh perlu ditambahkan asam fosfat encer untuk menurunkan $\mathrm{pH}$.

3. Pengaruh Pelapisan dengan Paraloid B 72

Dalam kajian ini dilakukan pengujian pengaruh coating dengan paraloid pada sampel yang telah diaplikasi dengan tanin (baik tannin dari ekstrak teh maupun tanin sintetik). Pengujian dilakukan dengan cara membandingkan sampel yang telah ditanin tidak di-coating dengan paraloid B72 (T.1.1, T.1.2, T.3.1, T.3.1, T.3.2, T.3.3, S.1.1, S.1.2, S.3.1, S.3.1, S.3.2, S.3.3) dan sampel yang telah ditanin di-coating dengan paraloid B72 (T.2.1, T.2.2, T.2.3. T.4.1, T.4.2, T.4.2, S.2.1, S.2.2, S.2.3. S.4.1, S.4.2, S.4.2). Hasil pengamatan terhadap sampelsampel tersebut menunjukan bahwa sampel yang di-coating paraloid permukaanya lebih tebal dan mengkilap. Sampel yang distabilkan dengan ekstrak teh dan di-coating dengan paraloid menunjukan permukaannya terlihat lebih terlindungi dibandingkan yang tidak dicoating.

Namun, sampel yang distabilkan dengan tanin sintetik menunjukan tidak ada perbedaan kenampakan pada sampel yang di-coating maupun tidak. Kemungkinan lapisan kompleks besitanin sintetik lebih tebal, sehingga tanpa di-coating paraloid permukaannya sudah mengkilap. Hasil tersebut menunjukan pelapisan paraloid sangat diperlukan pada sampel besi yang distabilkan

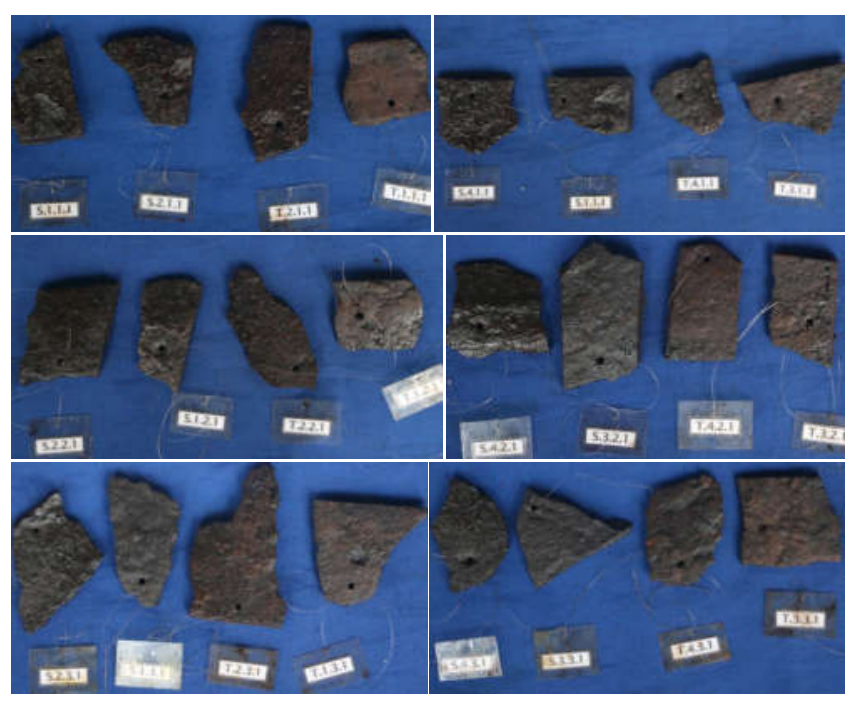

Perlakuan Sampel setelah ditanin tanpa di-coating Paraloid B72 dan Sampel setelah ditanin di-coating Paraloid B72 


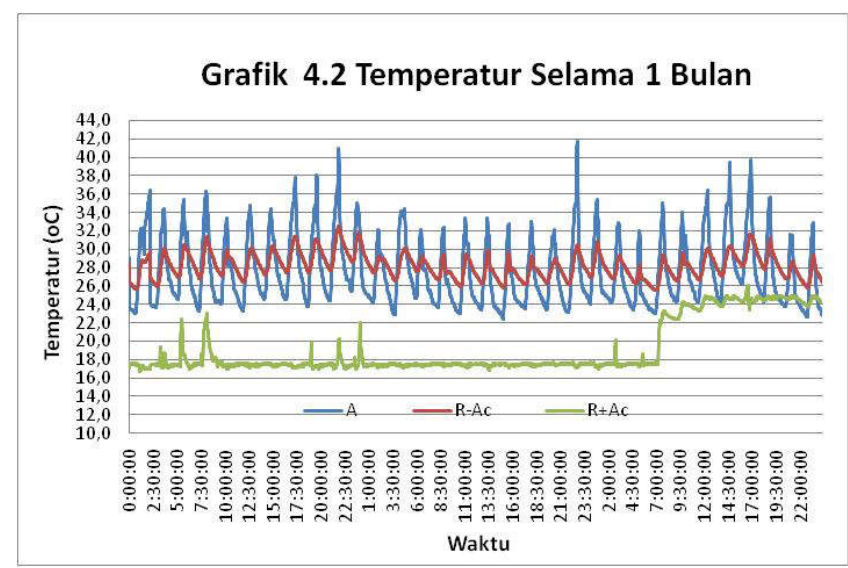

dengan ekstrak teh, namun pada sampel yang distabilkan dengan tanin sintetik tidak diperlukan. Seperti yang dijelaskan pada subbab B.1, lapisan kompleks besi-tanin sintetik lebih tebal dari pada besi-tanin dari ekstrak teh. Sehingga coating dibutuhkan jika lapisan tanin besi yang terbentuk tipis. Jika tanin yang terbentuk sudah tebal maka tidak di perlukan lapisan pelindung tambahan dalam hal ini pelapisan paraloid B72.

\subsection{Pengaruh Kondisi Lingkungan (Temperatur dan Kelembaban)}

1. Pengaruh Kondisi Lingkungan Terhadap Sampel yang Telah Ditanin

Dalam kajian ini dilakukan pengujian untuk mengetahui pengaruh lingkungan (suhu dan kelembaban) pada sampel besi yang telah distabilkan dengan tanin. Pengujian untuk membuktikan bahwa lamanya perlindungan tanin pada besi sangat dipengaruhi oleh kondisi lingkungan. Pengujian dilakukan dengan cara menempatkan sampel di luar ruangan (ruang terbuka), di dalam ruangan tanpa AC dan dalam ruang ber-AC.

Dalam pengujian ini ditempatkan alat data logger pada setiap tempat untuk memonitor temperature dan kelembaban pada masingmasing tempat. Grafik 4.2 menunjukan temperatur dalam ruangan tanpa AC cenderung stabil dengan kisaran $25,8-32,2^{\circ} \mathrm{C}$. Di luar ruangan sangat fluktuatif dan ekstrim (22 - 42 $\left.{ }^{\circ} \mathrm{C}\right)$ sedangkan temperature pada ruang berAC rendah dan cenderung stabil $\left(17,8-26{ }^{\circ} \mathrm{C}\right)$. Namun, adakalanya meningkat drastis karena

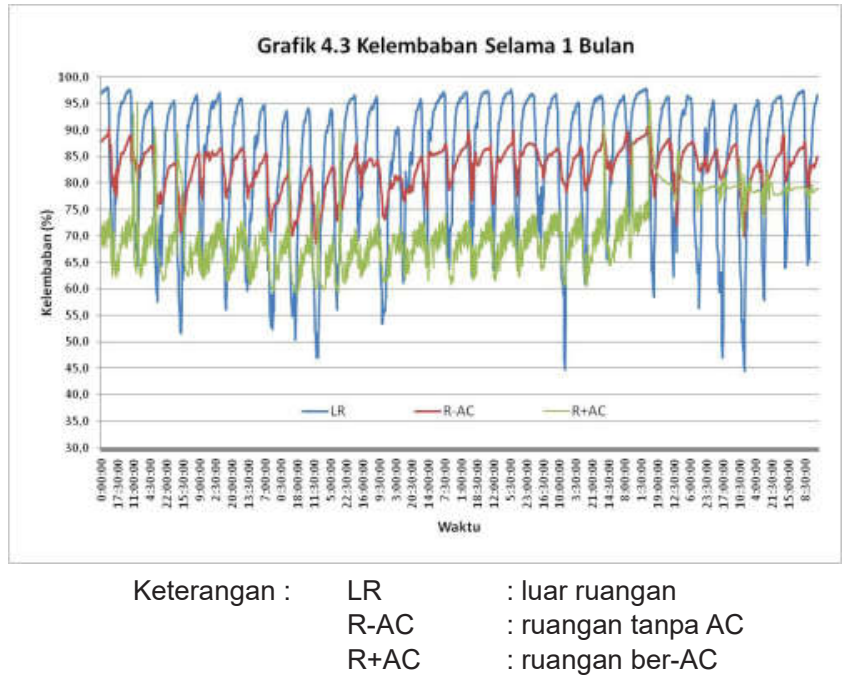

saat libur kantor dan ketika terjadi pengembunan AC dinaikan temperaturnya.

Grafik 4.3 menunjukan kelembaban udara dalam ruangan tanpa AC cenderung tinggi dan fluktuatif dengan kisaran 68-90\%. Di luar ruangan sangat fluktuatif dan ekstrim 45-98\% sedangkan kelembaban udara pada ruang ber-AC tinggi dan cenderung stabil (59-75\%). Namun, adakalanya kelembaban udara meningkat drastis sampai 90\% karena saat kantor libur dan ketika terjadi pengembunan maka AC dinaikan temperaturnya.

Ketiga kondisi lingkungan tersebut ternyata bukan merupakan kondisi yang ideal untuk artefak besi. Menurut Logan, Juddy (2007), kelembaban udara 50\% tidak akan merusak besi yang tidak mengadung garam terlarut yang tinggi. Namun, kelembaban udara di atas 65\% akan cepat merusak semua artefak besi.
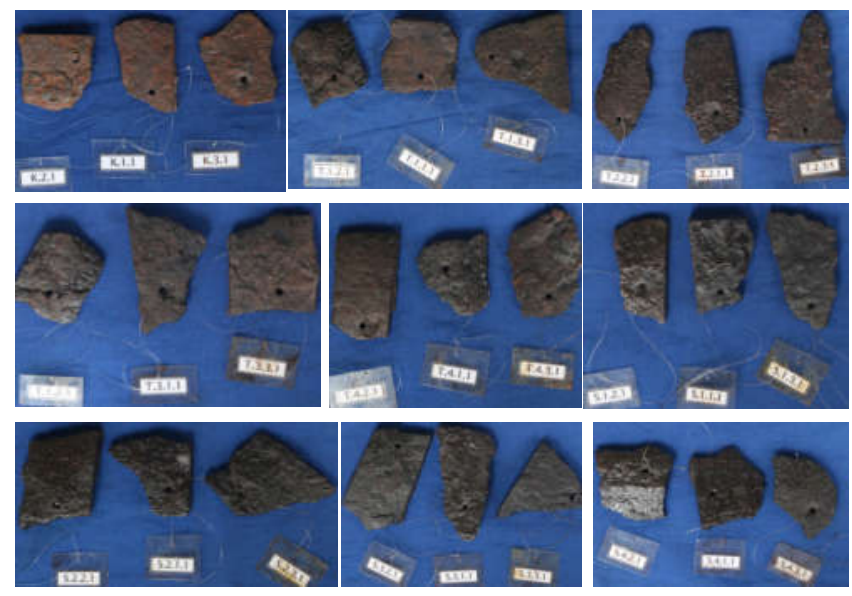

Sampel dalam Ruang tanpa AC, Sampel di Luar ruangan dan Sampel di dalam Ruangan Ber-AC 
Namun, hasil pengamatan terhadap permukaan sampel (Gambar 4.4) menunjukan belum ada perbedaan kenampakan pada sampel yang ditempatkan pada kondisi lingkungan yang berbeda. Hal ini kemungkinan terjadi karena waktu eksperimen yang masih pendek (8 minggu), sehingga perbedaan kondisi lingkungan (temperatur dan kelembaban) belum berperngaruh terhadap kondisi sampel. Oleh karena itu, untuk melihat pengaruh perbedaan kondisi lingkungan pada artefak besi yang telah distabilkan dengan tanin maka dilakukan pengamatan terhadap kondisi koleksi besi pada Museum Nasional.

2. Pengaruh Kondisi Lingkungan Pada Koleksi Besi di Museum Nasional

Pengamatan pengaruh kondisi lingkungan (temperatur dan kelembaban) terhadap koleksi besi yang berada pada gedung A (gendung lama), gedung $B$ (gedung baru) dan pada ruang penyimpanan (storage). Sampel koleksi besi yang diamati merupakan koleksi yang mewakili kondisi koleksi yang ada di setiap lokasi. Semua koleksi besi yang diamati merupakan koleksi besi yang telah distabilkan dengan tanin sintetik dan dilapisi dengan paraloid B72 sekitar tahun 2000. Koleksi besi yang disimpan dalam almari pada gedung lama ruang etnografi menunjukan kondisinya masih relatif bagus (hanya mengalami korosi pasif). Koleksi besi pada ruang pamer gedung baru lantai 2, yang disimpan dalam almari menunjukan tanda-tanda yang mengarah

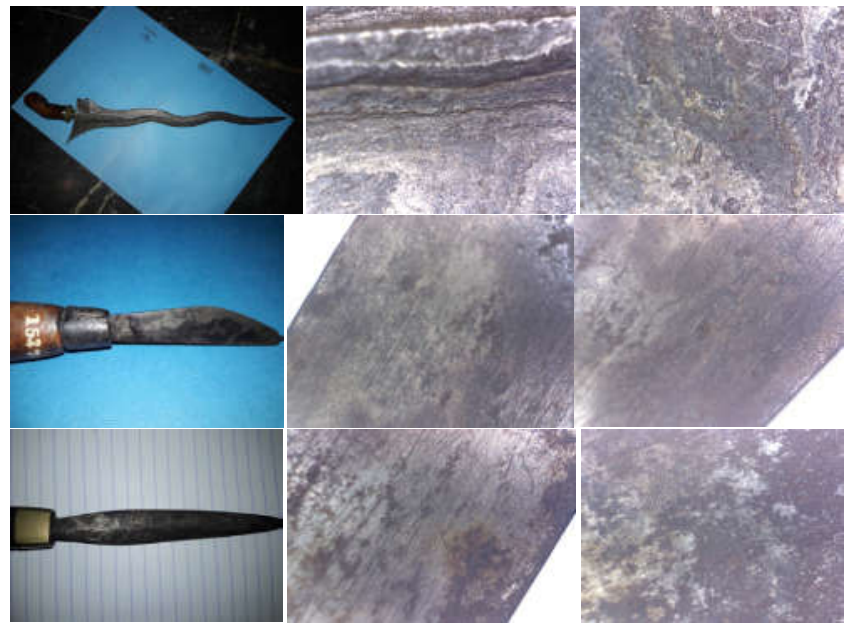

Kondisi Beberapa Koleksi Besi yang Disimpan dalam Almari pada Gedung Lama (Gedung A)

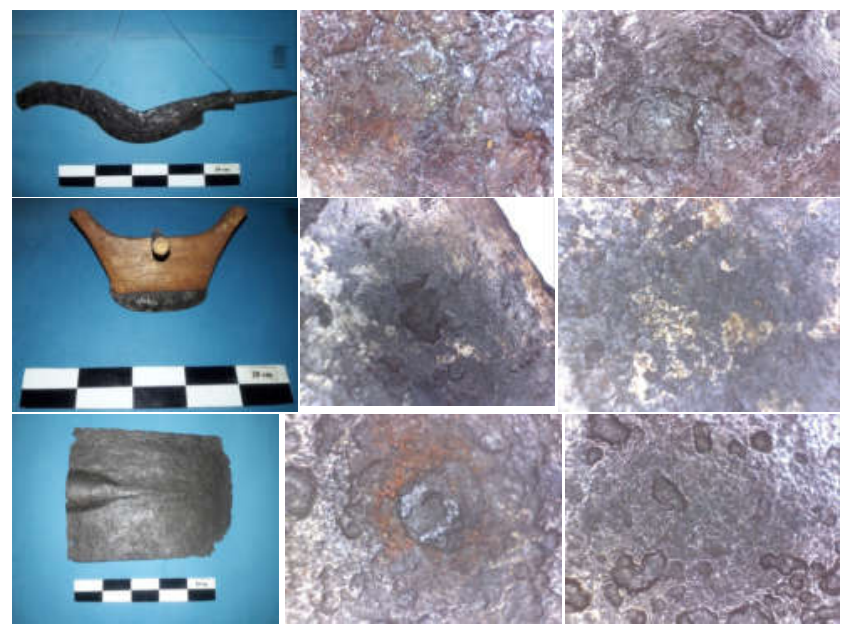

Kondisi Beberapa Koleksi Besi yang Disimpan dalam Almari pada Gedung Baru (Gedung B)

pada korosi aktif namun belum meluas Adapun koleksi besi yang disimpan pada rak besi dalam ruang penyimpanan gedung baru, menunjukan telah terjadi korosi aktif yang
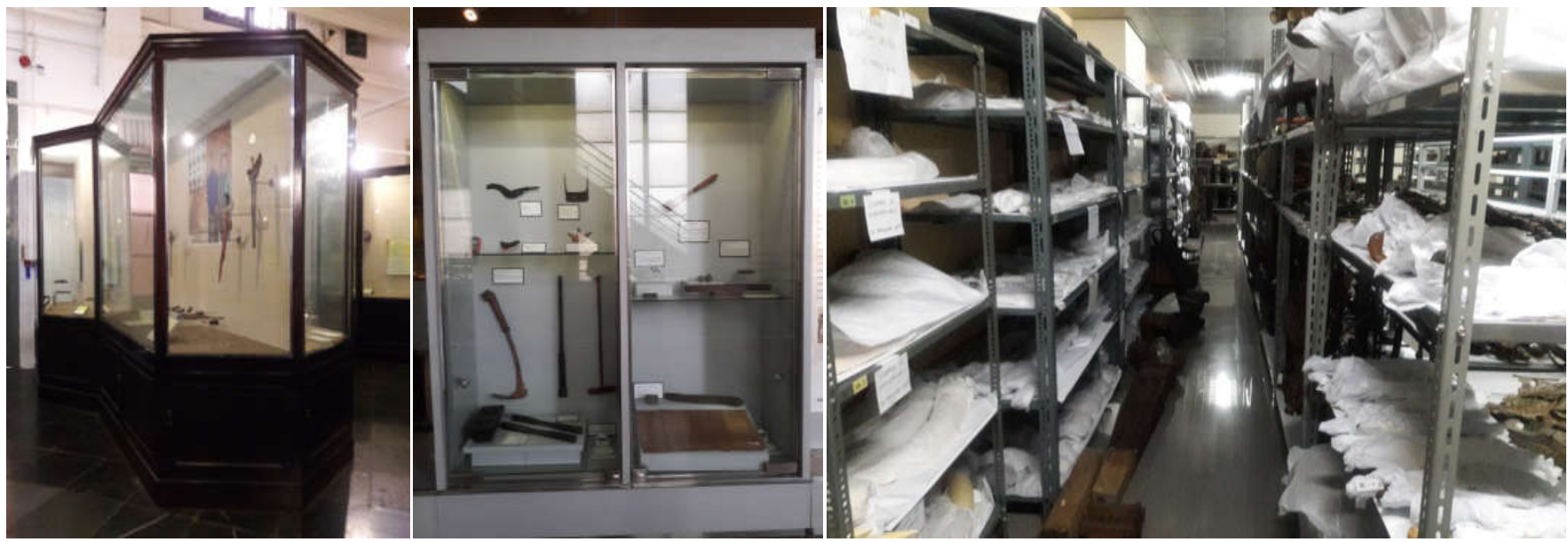

Almari digedung lama/A (kiri), Almari Gedung Baru /B (tengah), Rak di Ruang Storage (kanan) 

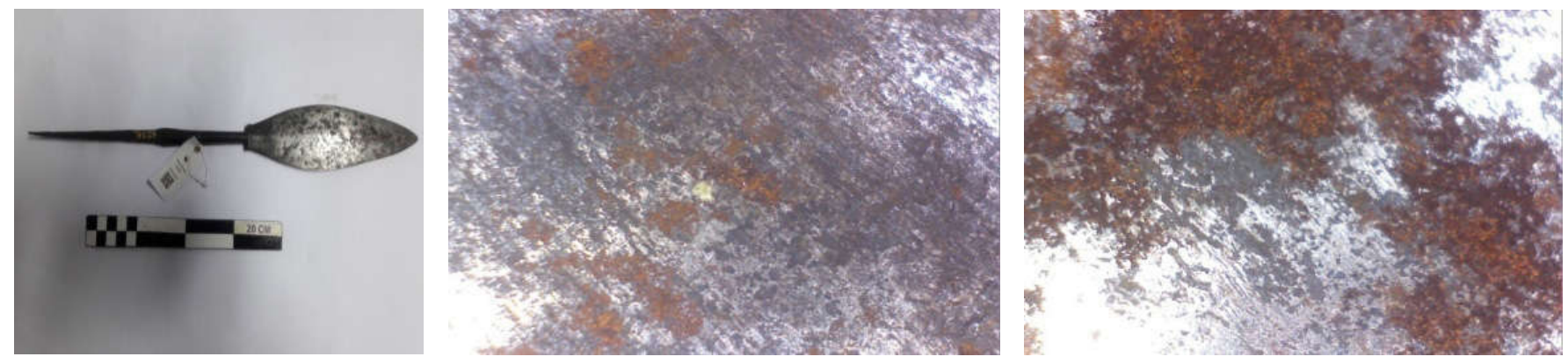

Kondisi Satu Koleksi Besi yang Disimpan dalam ALmari pada Gedung Baru (Gedung B)

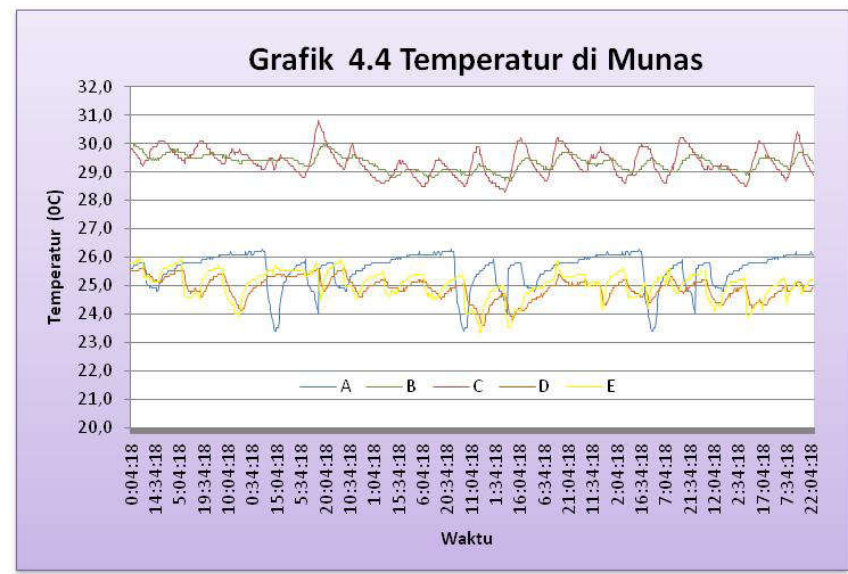

Keterangan:

A : ruang storage gedung B.baru

$B$ : ruang pamer etnografi/gedung $A$ /lama dalam almari

$\mathrm{C}$ : ruang pamer etnografi/gedung $\mathrm{A} /$ lama diluar almari

$\mathrm{D}$ : ruang pamer lantai $2 /$ gedung $\mathrm{B} /$ baru dalam almari

$\mathrm{E}$ : ruang pamer lantai $2 /$ gedung $\mathrm{B} / \mathrm{b}$ aru di luar almari

cenderung meluas.

Hasil pengamatan kondisi lingkungan selama 1 bulan terhadap temperatur pada setiap lokasi menunjukan bahwa temperatur dalam gedung A (lama) dalam ruang etnografi tinggi $\left(28,3-30,8^{\circ} \mathrm{C}\right)$ namun cenderung stabil, sedang temperatur dalam almari pada lokasi tersebut cenderung stabil namun masih tinggi (28,7$\left.30^{\circ} \mathrm{C}\right)$. Temperatur dalam ruang pamer lantai 2 gedung baru (B) sedang, namun sangat fluktuatif $\left(23,3-26^{\circ} \mathrm{C}\right)$. Adapun temperatur dalam almari pada lokasi tersebut sedang, namun cenderung fluktuatif $\left(23,6-25,4^{\circ} \mathrm{C}\right)$. Temperatur dalam ruang penyimpanan (storage) pada gedung baru (B), sedang namun sangat fluktuatif (23,3-26,2 $\left.{ }^{0} \mathrm{C}\right)$. Untuk lebih jelas, kondisi temperatur dapat dilihat pada Grafik 4.4.

Adapun data kelembaban pada masing-masing lokasi sebagai berikut; kelembaban pada ruang etnografi gedung lama (A) sangat fluktuatif (54-75\%), sedangkan kelembaban dalam almari

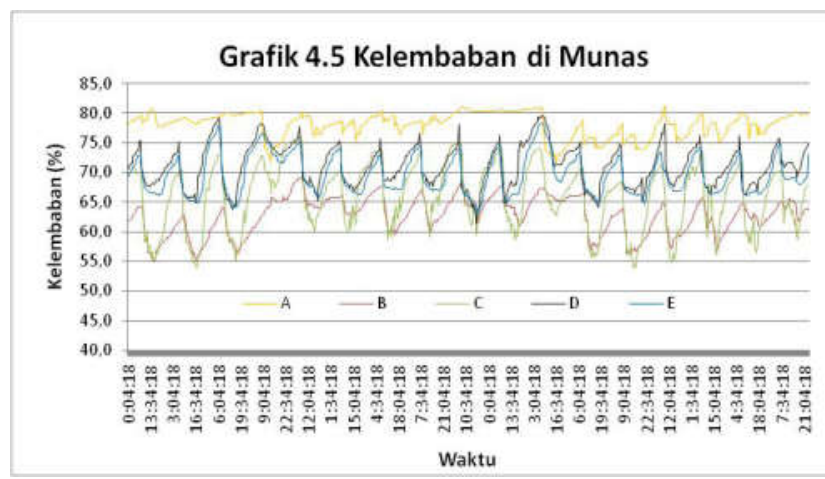

Keterangan:

$A$ : ruang storage gedung $B$.baru

$B$ : ruang pamer etnografi/gedung $A$ /lama dalam almari

$C$ : ruang pamer etnografi/gedung $A / l a m a$ diluar almari

$\mathrm{D}$ : ruang pamer lantai $2 /$ gedung $\mathrm{B} /$ baru dalam almari

$\mathrm{E}$ : ruang pamer lantai $2 /$ gedung $B /$ baru di luar almari

sedang dan stabil (55-68\%). Kelembaban udara ruang pamer, lantai 2 gedung baru (B) tinggi dan cenderung stabil (63-78\%) sedangkan kelembaban dalam almari tinggi dan cenderung lebih fluktuatif (61-79\%). Kelembaban dalam ruang penyimpanan sangat tinggi dan fluktuatif (72-81\%). Data kelembaban secara lengkap dapat dilihat pada Grafik 4.5

Gambaran lebih jelas tentang kondisi koleksi besi dan kondisi lingkungan dapat dilihat pada Tabel 4.4.

Berdasarkan Tabel 4.3 dapat dilihat bahwa koleksi besi pada ruang etnografi gedung lama cenderung lebih awet dari pada dalam gedung baru dan ruang storage. Hal ini karena kondisi lingkungannya cenderung stabil. Kelembaban udara dalam almari ruang etnografi masih pada kisaran sedang dan cenderung stabil. Temperatur tinggi sampai $30^{\circ} \mathrm{C}$ namun cenderung stabil. Kondisi ini mungkin yang menyebabkan artefak besi dalam lokasi tersebut lebih awet. Suhu bukan merupakan faktor pemicu utama terjadinya korosi. Namun, kelebaban udara yang tinggi 
Tabel 4.4 Gambaran Kondisi Koleksi Besi dan Kondisi Lingkungannya

\begin{tabular}{|c|c|c|c|c|c|c|c|}
\hline \multirow{2}{*}{$\begin{array}{l}\text { Kondisi } \\
\text { Koleksi }\end{array}$} & \multirow{2}{*}{ Lokasi } & \multicolumn{2}{|c|}{$\begin{array}{l}\text { Temperatur udara } \\
\qquad\left({ }^{\circ} \mathrm{C}\right)\end{array}$} & \multirow{2}{*}{ Keterangan } & \multicolumn{2}{|c|}{$\begin{array}{c}\text { Kelembaban udara } \\
(\%)\end{array}$} & \multirow{2}{*}{ Keterangan } \\
\hline & & range & selisih & & range & selisih & \\
\hline $\begin{array}{l}\text { Korosi aktif } \\
\text { cenderung } \\
\text { meluas }\end{array}$ & A & $23,3-26,2$ & 2,9 & $\begin{array}{c}\text { sedang } \\
\text { sangat } \\
\text { fluktuatif }\end{array}$ & $72-81$ & 9 & $\begin{array}{l}\text { sangat } \\
\text { tinggi, } \\
\text { stabil }\end{array}$ \\
\hline \multirow[t]{2}{*}{$\begin{array}{l}\text { Bagus, } \\
\text { korosi pasif }\end{array}$} & B & $28,7-30,0$ & 1,3 & $\begin{array}{l}\text { tinggi, } \\
\text { cederung stabil }\end{array}$ & $55-68$ & 13 & $\begin{array}{l}\text { sedang, } \\
\text { cenderung stabil }\end{array}$ \\
\hline & C & $28,7-30,0$ & 2,5 & $\begin{array}{l}\text { tinggi, sangat } \\
\text { fluktuatif }\end{array}$ & $54-75$ & 21 & sangat fluktuatif \\
\hline \multirow[t]{2}{*}{$\begin{array}{l}\text { Korosi aktif, } \\
\text { belum meluas }\end{array}$} & D & $23,6-25,4$ & 1,8 & $\begin{array}{l}\text { sedang, } \\
\text { fluktuatif }\end{array}$ & $61-79$ & 18 & tinggi, fluktuatif \\
\hline & $E$ & $23,3-26,0$ & 2,7 & $\begin{array}{l}\text { sedang, sangat } \\
\text { fluktuatif }\end{array}$ & $63-78$ & 13 & $\begin{array}{l}\text { tinggi, cenderung } \\
\text { stabil }\end{array}$ \\
\hline
\end{tabular}

Keterangan:

A : ruang storage gedung B.baru

$B$ : ruang pamer etnografi/gedung $A$ /lama dalam alemari

$\mathrm{C}$ : ruang pamer etnografi/gedung $\mathrm{A} /$ lama diluar alemari

dan fluktuatif akan mempercepat terjadinya korosi seperti yang terjadi pada koleksi di ruang storage. Kelembaban tinggi, berarti jumlah uap air dalam udara cukup banyak. Jumlah uap air yang banyak di udara menyebabkan terjadinya korosi. Koleksi besi yang telah distabilkan dengan tanin dan dilapisi paraloid lebih terawetkan jika berada pada lingkungan yang cenderung stabil dan kelembaban sedang. Berdasarkan hasil tersebut diketahui bahwa lamanya perlindungan kompleks besi-tanin terhadap koleksi besi sangat dipengaruhi oleh kondisi lingkungan terutama kelembaban udara.

\section{Kesimpulan dan Saran}

\section{A. Kesimpulan}

1. Kandungan ekstrak daun teh tua asal Nglinggo $12,11 \%$ dan kandungan ekstrak daun teh mudanya $12,61 \%$

2. Kandungan tanin dalam daun teh tua asal Nglinggo 1,78\% dan kandungan tanin dalam daun teh mudanya 2,69\%

3. Tanin dari ekstrak teh dapat menghambat korosi pada artefak besi namun kemampuannya masih di bawah tanin sintetik.

4. Dalam aplikasi larutan ekstrak untuk stabilisasi
$\mathrm{D}$ : ruang palummer lantai $2 /$ gedung $\mathrm{B} / \mathrm{baru}$ dalam alemari

$\mathrm{E}$ : ruang pamer lantai $2 /$ gedung $\mathrm{B} /$ baru di luar alemari

besi perlu penambahan asam fosfat untuk mencapai $\mathrm{pH}$ optimum

5. Pelapisan coating dibutuhkan jika lapisan tanin besi yang terbentuk tipis. Jika tanin yang terbentuk sudah tebal maka tidak diperlukan lapisan pelindung tambahan.

6. Pelapisan atau coating diperlukan pada artefak yang distabilkan dengan ekstrak teh

7. Lamanya perlindungan kompleks besi-tanin terhadap artefak besi sangat dipengaruhi oleh kondisi lingkungan terutama kelembaban udara.

8. Besi yang telah distabilkan dengan tanin dan dicoating akan lebih terawetkan jika berada pada lingkungan yang stabil dengan kelembaban udara di bawah 50\% jika masih mengandung klor dan di bawah 65\% jika sudah tidak mengandung klor.

\section{B. Saran}

1. Stabilisasi artefak besi dengan tanin dari ekstrak teh sebaiknya dilakukan ketika tidak didapatkan tanin sintetik

2. Aplikasi tanin dari ekstrak teh perlu ditambahkan asam fofat encer untuk menurunkan $\mathrm{pH}$ larutan. Namun untuk aplikasi tanin sintetik tidak perlu ditambahkan larutan asam fosfat encer 
3. Setelah stabilisasi dengan tanin dari ekstrak teh sebaiknya dilanjutkan dengan pelapisan (coating) untuk perlindungan tambahan.

Besi yang telah ditanin dan dicoating sebaiknya disimpan lingkungan dengan kelembaban kelembaban udara di bawah 50\% jika masih mengandung klor dan di bawah 65\% jika sudah tidak mengandung klor.

\section{DAFTAR PUSTAKA}

\section{Literatur/Texbook}

Hamilton, Donny. 1999. Methods of Conserving Archaeological Material from Underwater Sites. Center for Marine Archaeology and Conservation Texas A \& M University.

Sadirin, Hr. 1984. Konservasi dan Preservasi BendaBenda Perunggu. Balai Konservasi Candi Borobudur.

\section{Publikasi Hasil Penelitian, Skripsi, Tesis dan Artikel}

Dalimunthe, IS. 2004. Kimia dari Inhibitor. Program Studi Teknik Kimia, Fakultas Teknik. Universitas Sumatera Utara.

Irianty, RS dan Komalasari. 2013. Ektraksi Daun Gambir Menggunakan Pelarut Metanol-Air sebagai Inhibitor Korosi. Laboratorium Konversi Elektrokimia, Jurusan Teknik Kimia, Universitas Riau. Jurnal Teknobiologi, IV (1) 2013:7-15 ISSN:2087 - 5428

Logan, Judy. 2007. Recognizing Active Corrosion. CCI Note 9/1. Canadian Conservation Institute. Minister of Public Works and Government. ISSN: 0714-6221

Logan, Judy. 2007. Care and Cleaning of Iron. CCI Note 9/6. Canadian Conservation Institute. Minister of Public Works and Government. ISSN: 0714-6221 Logan, Judy. 2013. Tannic Acid Coating for Rusted Iron Artifacts. CCI Notes 9/5 Canadian Conservation Institute. Minister of Public Works and Government. ISSN: 0714-6221

Maaß, Peter and Peibker, Peter. 2011. Corrosion and Corrosion Protection. Wiley-vch Verlag Gmbh and Co. KgaA. Weinheim. ISBN: 978-3-52732324-1

Munandar, A. 2007. Teknik Konservasi Benda-Benda Logam. Makalah disampaikan dalam Pelatihan Tenaga Teknis Konservasi, Balai Konservasi Borobudur pada tangga 17 Juli 2012.1
Pelikan, J.B. 1966. Conservation of Iron with Tannin. Situs in Conservation. Money Publishing International Institute for Conservation of History and Artistic. Vol 11. No.3 (Augs, 1966).

Prevey, P.S., Jayaraman, N and Cammett, John, T. 2003. Mitigation of Active Corrosion Fatigue and Corrosion Pit Initiated Fatigue in AA 7075-T6 with Low Plasticity Burnishing. ASIP Conferenc, in December 2-4, 2003, Lambda Technologies.

Mircea, O., Sandu, I., Sarghie and Sandu, AV. 2010. The Identified Effects of Degradation in Archeological Artefacts with Overlapped Metals Used in Authentication. International Jurnal of Conservation Science. Volume 1, Issue 1, JanuariMarch 2010: 27-40. ISSN: 2067-533X.

Munandar, Aris. 2014. Konservasi Benda Cagar Budaya Berbahan Besi, Perunggu dan Kuningan. Makalah disampaiakan dalam Diskusi Prakajian Metode Konservasi Tradisional, tanggal 8 April 2014 di Hotel Grand Artos Magelang.

Siregar, Uli Cynthia Rahayu. 2009. Kualitas Perekat Tanin dari Beberapa Kulit Kayu Mangrove. Skripsi. Teknologi Hasil Hutan, Departemen Kehutanan, Fakultas Pertanian, Universitas Sumatra Utara, Medan.

Sunarno. 2010. Penanganan Konservasi: Perawatan dan Restorasi Kayu. Makalah disampaikan dalam Bimbingan Teknis Konservasi Peninggalan Bawah Air, Direktorat Peninggalan Bawah Air. Direktorat Jenderal Sejarah dan Purbakala.

Swastikawati, A. 2014. Metode Konservasi Logam Secara Tradisional. Laporan Kajian. Balai Konservasi Borobudur, 2014

\section{Website}

Hermawan, Beni. 2007. Ekstrak Bahan Alam sebagai Alternatif Inhibitor Korosi. http://www. Chem.is-try.org. Dikutip tanggal 30 April 2015. 